\title{
The Effect of Career Development and Job Promotion on Employee Morale
}

\author{
Juris Tupadela ${ }^{1}$ \\ ${ }^{1}$ Proposal Penelitian Prodi Manajemen UM Bengkulu 2020
}

\begin{abstract}
This study aims to determine the effect of Career Development and Job Promotion on the Employee Morale of PDAM Kota Bengkulu. This research is a quantitative study with saturated or census sampling techniques. Data collection techniques using a sample of 130 respondents, using observations and questionnaires. Engineering the data analysis using the classic assumption test, multiple linear regression, coefficient of determination (R2) and hypothesis testing.

Keywords: Career Development, Job Promotion and Employee Morale
\end{abstract}

\section{BAB I \\ PENDAHULUAN}

\subsection{Latar Belakang}

Sumber Daya Manusia (SDM) mempunyai kedudukan yang paling penting bagi organisasi atau perusahaan. SDM juga merupakan kunci yang menentukan perkembangan perusahaan. Dalam hal ini SDM berupa manusia yang dipekerjakan di sebuah organisasi sebagai penggerak untuk mencapai tujuan organisasi itu. Hasil kerja yang baik akan dicapai apabila seluruh anggota organisasi mempunyai semangat kerja.

Oleh karena itu SDM harus dikelola dengan baik untuk meningkatkan kinerjanya dalam organisasi itu. Aktivitas yang sering dijumpai dalam SDM ialah merangsang, mengembangkan, memotivasi, dan memelihara kinerja yang tinggi 
di dalam organisasi serta semua aktivitas yang dilakukan dalam SDM tidak menentang norma-norma dalam masyarakat.

Manajemen karir yang terstruktur dan terencana dengan baik akan mengandung makna bahwa pihak manajemen perusahaan sangat memperhatikan pengembangan karir karyawannya. Dimana pada umumnya karyawan tidak semata-mata untuk mencari uang sebagai kebutuhan pokok, tetapi seorang karyawan ingin mengembangkan diri dan meningkatkan karir agar dapat menduduki jabatan yang lebih tinggi ditempatnya bekerja. Karyawan mengharapkan sesuatu yang memberikan keuntungan terhadap dirinya namun juga membutuhkan kepastian akan kelangsungan karir mereka diperusahaan. Maka untuk menumbuhkan semangat kerja karyawan perlu adanya promosi jabatan tetapi disertai pula dengan pengembangan karir.

"Pengembangan karir adalah aktivitas sumber daya manusia yang membantu karyawan dalam merencanakan karir masa depan mereka di perusahaan agar perusahaan dan pegawai yang bersangkutan dapat mengembangkan diri secara maksimum' (Mangkunegara, 2017, Onsardi, O., 2020, Juita, R., 2020). Sedangkan menurut Sinambela (2016) "pengembangan karir adalah upaya yang dilakukan oleh organisasi dalam merencanakan karir pegawainya, yang disebut manajemen karir, antara lain merencanakan, melaksanakan, dan mengawasi karir. pengembangan karir juga bisa meningkatkan kinerja karyawan'. Menurut (Regina, 2013) “pengembangan karir merupakan pendekatan formal yang dilakukan organisasi untuk menjamin orang-orang dalam 
organisasi mempunyai kualifikasi, kemampuan, dan pengalaman yang cocok ketika dibutuhkan".

Adanya pengembangan karir di suatu perusahaan maka menunjukkan kualitas kinerja karyawan akan semakin meningkat. sebagai contoh, penelitian yang dilakukan oleh Kakui dan Gachunga (2016); Ali, dkk (2016); dan Nasution, dkk (2018), dimana hasil penelitian menunjukkan bahwa "pengembangan karir memiliki pengaruh positif dan signifikan terhadap kinerja karyawan, pengembangan karir dapat membuat karyawan lebih termotivasi untuk meningkatkan kinerja'’

Dengan melakukan pengembangan karir tentu kualitas karyawan pun meningkat. Salah satu langkah yang harus dilakukan perusahaan untuk mengembangakan karyawannya adalah melalui promosi jabatan.

"Promosi jabatan adalah perpindahan yang memperbesar wewenang (authority) dan tanggung jawab (resposibility) karyawan ke jabatan yang lebih tinggi di dalam satu organisasi sehingga kewajiban, hak, status, dan penghasilannya semakin besar' Hasibuan (2008:108). Menurut Ardana, dkk (2012:106) "promosi jabatan ialah suatu proses perubahan dari suatu pekerjaan ke suatu pekerjaan yang lain, pada hierarki wewenang dan tanggung jawab yang lebih tinggi dibandingkan dengan wewenang dan tanggung jawab yang telah dibebankan kepada diri karyawan pada waktu sebelumnya'. Sehingga promosi jabatan sangat berpengaruh terhadap semangat kerja karyawan, penelitian yang dilakukan Thoriq, dkk (2017) yang menemukan bahwa "promosi jabatan 
pada posisi yang tinggi dapat menghasilkan semangat kerja yang tinggi pula'. Apabila keinginan karyawan terpenuhi maka akan timbul kepuasan dalam dirinya. Perasaan puas ini yang akan mendorong semangat kerja karyawan.

Berkaitan dengan semangat kerja, menurut Murdani (2012), “'semangat kerja adalah kemampuan atau kemauan setiap individu atau sekelompok orang untuk saling bekerja sama dengan giat, tekun dan disiplin serta penuh rasa tanggung jawab disertai kesukarelaan dan kesediaannya untuk mencapai sebuah tujuan organisasi". Hendri (2010) mengungkapkan bahwa "semangat kerja karyawan adalah sikap mental dari individu maupun kelompok yang menunjukkan kesungguhannya di dalam melaksanakan pekerjaan sehingga mendorong untuk bekerja lebih baik'”

Perusahaan Daerah Air Minum (PDAM) Tirta Dharma Kota Bengkulu salah satu perusahaan yang dikelola daerah yang berfungsi melayani kebutuhan publik, harus memperhatikan tingkat kepuasan konsumen akan mutu pelayanan. Agar PDAM Kota Bengkulu dapat menjalankan fungsinya, maka PDAM Kota Bengkulu harus selalu meningkatkan kinerja para pegawainya karena pegawai bertindak sebagai perencana dan pelaku aktif dalam setiap aktivitas perusahaannya.

Sudah seharusnya PDAM turut berpacu meningkatkan kualitas. Baik kualitas produksi dengan menjaga ekosistem sekitar sumber mata air maupun kualitas layanan serta fasilitas saluran, mengingat semakin melonjaknya permintaan akan air dari masyarakat. 
Besarnya kebutuhan air ini sehingga meningkatkan peluang daerah untuk mendapatkan keuntungan dari bertambahnya permintaan pemasangan PDAM. Dari peningkatan pengguna layanan PDAM tersebut seingga berdampak meningkatnya kinerja PDAM Kota Bengkulu. Peningkatan kinerja selalu didahului dengan semangat kerja membuat PDAM harus segera melakukan pembenahan. Jika PDAM tidak segera melakukan pembenahan dalam berbagai hal maka bukan tidak mungkin akan menyebabkan ketertinggalan dengan perusahaan sejenis lainnya maupun badan usaha milik daerah yang lain.

Dari pengamatan yang dilakukan di PDAM Tirta Dharma Terkait dengan permasalahan semangat kerja, masih banyak karyawan yang kurang semangat dalam bekerja, seperti ditunjukkan dengan perilaku karyawan yang lebih mementingkan absensi dari pada penyelesaian pekerjan, karyawan pada kelompok ini datang dan pulang tepat waktu namun kegiatannya di perusahaan lebih banyak menghabiskan waktu di kantin, membicarakan hal-hal yang tidak penting dan halhal yang tidak produktif lainnya. Hasil wawancara dengan Kuswanto Kepala bagian transmisi atau distribusi pada hari senin tanggal 11 November 2019, pukul 10.00 WIB di PDAM Kota Bengkulu.

Didukung wawancara dengan Khairi sebagai salah satu karyawan tetap bagian umum di PDAM pada hari senin tanggal 11 November 2019, pukul 14.15 WIB di PDAM Kota Bengkulu. Hasil wawancara menunjukan bahwa karyawan mengalami ketidaksemangatan ketika dihadapkan dengan banyaknya pekerjaan dan promosi jabatan belum berjalan dengan baik. 
Didukung pula wawancara dengan Tika salah satu karyawan bagian SDM umum di PDAM Kota Bengkulu. Hasil wawancara menunjukkan bahwa penanganan perusahaan tidak sesuai keinginan, tidak ada timbal balik yang tepat dalam meningkatkan semangat kerja karyawan, dimana pengembangan karir belum berjalan dengan semestinya.

Hal ini menyebabkan semangat kerja menjadi sangat diperhatikan oleh perusahaan, akan tetapi penanganan yang diberikan masih kurang sesuai dengan keinginan karyawan yang berakibat tetap rendahnya semangat kerja karyawan dan bahkan semakin mengalami ketidaksemangatan kerja.

Untuk membuktikan kebenaran permasalahan ini maka akan dikaji lebih mendalam apakah pengembangan karir dan promosi jabatan dapat mempengaruhi semangat kerja karyawan pada PDAM Tirta Dharma Kota Bengkulu.

\subsection{Identifikasi Masalah}

Berdasarkan uraian tersebut, maka penulis mengidentifikasi masalah sebagai berikut:

1. Semangat kerja masih rendah

2. Pengembangan karir belum berjalan dengan semestinya

3. Promosi jabatan belum berjalan dengan baik

4. Kurangnya tanggung jawab

5. Kurangnya kedisiplinan 


\subsection{Pembatasan Masalah}

Agar penelitian ini terarah dan masalah yang diteliti tidak terlalu luas maka penelitian ini perlu adanya pembatasan masalah, pembatasan masalah pada penelitian ini yaitu, pengembangan karir, promosi jabatan dan semangat kerja karyawan PDAM Tirta Dharma Kota Bengkulu.

\subsection{Rumusan Masalah}

Berdasarkan latar belakang yang telah dikemukakan sebelumnya, maka permasalahan penellitian yang diangkat adalah :

1. Apakah pengembangan karir karyawan berpengaruh terhadap semangat kerja karyawan PDAM Kota Bengkulu?

2. Apakah promosi jabatan karyawan berpengaruh terhadap semangat kerja karyawan PDAM Kota Bengkulu?

3. Apakah pengembangan karir dan promosi jabatan karyawan berpengaruh terhadap semangat kerja karyawan PDAM Kota Bengkulu?

\subsection{Tujuan Penelitian}

Berdasarkan rumusan masalah dapat didentifikasikan tujuan dalam penelitian ini sebagai berikut :

1. Untuk mengetahui pengaruh pengembangan karir terhadap semangat kerja karyawan PDAM Kota Bengkulu.

2. Untuk mengetahui pengaruh promosi jabatan terhadap semangat kerja karyawan PDAM Kota Bengkulu. 
3. Untuk mengetahui pengaruh pengembangan karir dan promosi jabatan terhadap semangat kerja karyawan PDAM Kota Bengkulu.

\subsection{Manfaat Penelitian}

Hasil penelitian tentang pengaruh pengembangan karir dan promosi jabatan terhadap semangat kerja karyawan pada PDAM Kota Bengkulu diharapkan bermanfaat untuk:

1. Hasil penelitian ini diharapkan dapat memberikan masukkan dan menjadi bahan pertimbangan bagi para pengambil keputusan kebijakan untuk meningkatkan semangat kerja karyawan.

2. Bagi praktisi sebagai masukkan dalam rangka meningkatkan semangat kerja karyawan melalui pengembangan karir dan promosi jabatan.

3. Sebagai masukkan bagi para akademis agar dapat memberi pengetahuan tentang ilmu Sumber Daya Manusia dalam menjelaskan pengaruh pengembangan karir dan promosi jabatan terhadap semangat kerja karyawan.

\section{BAB II}

\section{TINJAUAN PUSTAKA}

\subsection{Deskripsi Konseptual}

\subsubsection{Pengertian Semangat Kerja}

Semangat kerja ialah sikap mental dari individu atau kelompok yang menunjukkan kegairahan untuk melakankan pekerjaannya sehingga mendorong untuk mampu bekerja sama dan dapat menyelesaikan tugas 
tepat pada waktunya dengan penuh rasa tanggung jawab terhadap pekerjaan yang dibebankan kepadanya.

Untuk membahas semangat kerja maka ada banyak para ahli memberikan definisi semangat kerja dari sudut pandang yang berbeda. Menurut Moekijat (2010;131), "Semangat atau moril kerja adalah kemampuan sekelompok orang untuk bekerja sama dengan giat dan konsekuen dalam mengejar tujuan bersama', Bekerja sama menekankan dengan tegas hakikat saling berhubungan dari suatu kelompok dengan keinginan yang nyata untuk bekerja sama.

“Semangat kerja adalah keinginan dan kesungguhan seseorang mengerjakan pekerjaannya dengan baik serta berdisiplin untuk mencapai prestasi kerja yang maksimal" Hasibuan (2012:94). Dengan giat dan konsekuen menunjukkan caranya untuk sampai kepada tujuan melalui disiplin bersama, Semangat kerja yang tinggi ialah bentuk nyata dari karyawan yang bekerja dengan berenergi, dan antusias. Sedangkan menurut (Alex S Nitisemito, 2010) menyatakan bahwa "semangat kerja adalah suatu iklim atau suasana kerja yang terdapat di dalam suatu organisasi yang menunjukkan rasa kegairahan di dalam melaksanakan pekerjaan dan mendorong mereka untuk bekerja secara lebih baik dan lebih produktif'. Sedangkan menurut Munandar (2014:51), mendefinisikan "semangat kerja adalah suatu sikap positif yang memandang pekerjaan sebagai hal yang penting ditandai dengan sikap melakukan pekerjaan dengan sungguh-sungguh atau optimal', 
Berdasarkan pendapat para ahli diatas dapat disimpulkan bahwa semangat kerja merupakan gambaran perasaan seseorang yang mempunyai keinginan dan kesungguhan memiliki kedisiplinan untuk mencapai prestasi kerja yang maksimal dan menunjukkan rasa kegairahan di dalam melaksanakan pekerjaan dan mendorong mereka untuk bekerja secara lebih baik dan lebih produktif.

\subsubsection{Faktor-Faktor Untuk Mengukur Semangat Kerja}

Dalam suatu perusahaan peningkatan semangat kerja karyawan merupakan suatu hal yang sangat penting. Karyawan yang memiliki semangat kerja yang tinggi akan bekerja sama dengan giat dan konsekuen dalam mengejar tujuan bersama sehingga memberikan keuntungan bagi perusahaan dan sebaliknya semangat kerja yang rendah akan mendatangkan kerugian pada perusahaan. Oleh karena itu pimpinan perusahaan harus mengetahui faktor-faktor yang dapat mengukur semangat kerja.

Menurut Nitisemito dan Darmawan (2013:80) faktor-faktor untuk mengukur semangat kerja adalah:

1. Absensi

Karena absensi menunjukkan ketidakhadiran karyawan dalam tugasnya. Hal ini termasuk waktu yang hilang karena sakit, kecelakaan dan pergi meninggalkan pekerjaan karena alasan pribadi tanpa diberi wewenang. Yang tidak diperhitungkan sebagai absensi 
adalah diberhentikan untuk sementara, tidak ada pekeerjaan, cuti yang sah libur dan pemberhentian kerja.

2. Kerja sama

Kerja sama dalam bentuk tindakan kolektif seseorang terhadap orang lain. Kerjasama dapat dilihat dari kesediaan karyawan untuk bekerja sama dengan rekan kerja atau dengan atasan mereka berdasarkan untuk mencapai tujuan bersama. Selain itu, kerjasama dapat dilihat dari kesediaan untuk saling membantu di anatara rekan sekerja sehubungan dengan tugas-tugasnya dan terlihat keaktifan dalam kegiatan organisasi.

3. Kepuasan kerja

Kepuasan kerja sebagai keadaan emosional yang menyenangkan atau tidak menyenangkan dimana para karyawan memandang pekerjaan mereka.

4. Kedisiplinan

Kedisiplinan sebagai suatu sikap dan tingkah laku yang sesuai peraturan organisasi dalam bentuk tertulis maupun tidak. Dalam prakteknya bila suatu organisasi telah mengupayakan sebagian besar dari peraturan-peraturan yang ditaati oleh sebagian besar karyawan, maka kedisiplinan telah dapat ditegakkan. Dan harus dapat di terapkan di perusahaan. 
Dari pendapat para ahli dapat disimpulkan bahwa fakor-faktor di atas sangat mempengaruhi tinggi rendahnya semangat kerja karyawan. Maka dari itu pimpinan perusahaan harus selalu memperhatikan faktorfaktor tersebut. Jika semangat kerja karyawan tinggi maka ini bukan masalah tetapi harapan organisasi, tetapi jika semangat kerja rendah maka akan sangat merugikan perusahaan. Sehingga sangat penting semangat dalam bekerja terus tetap terjaga.

\subsubsection{Cara Meningkatkan Semangat Kerja}

Pembinaan semangat kerja pegawai sangat penting dan perlu dilakukan terus menerus agar mereka menjadi terbiasa memiliki semangat kerja yang tinggi dan penuh gairah. Dengan demikian pegawai dapat melakukan pekerjaannya dengan baik dan kreatif. Hal ini sangat penting bagi kelangsungan hidup karyawan di perusahaan. Maka peusahaan harus berupaya untuk memelihara semangat kerja karyawan dengan melakukan berbagai cara. Menurut Nitisimito (2014:200) cara-cara tersebut antara lain:

1. Gaji yang cukup:

Setiap perusahaan harusnya dapat memberikan gaji yang cukup kepada karyawanya. Pengertian cukup disini relatif, artinya mampu dibayarkan tanpa menimbulkan kerugian bagi perusahaan. Sehinggah para karyawan dapat terjamin keuangannya dalam bekerja.

2. Memperhatikan kebutuhan rohani 
Selain kebutuhan materi yang terwujud gaji yang cukup, para karyawan membutuhkan kebutuhan rohani. Kebutuhan rohani adalah menyediakan tempat ibadah, menghormati kepercayaan orang lain.

3. Perlu menciptakan suasana santai

Suasana rutin sering kali menimbulkan kebosanan dan ketegangan bagi para karyawan untuk menghindari hal tersebut, maka perlu perusahaan sekali-kali menciptakan suasana santai dan rekreasi bersama-sama, mengadakan perbandingan olahraga antar karyawan yang lainnya.

4. Tempatkan karyawan pada posisi yang tepat

Setiap perusahaan harus mampu menempatkan pada posisi yang tepat, artinya menempatkan mereka pada posisi yang sesuai dengan keterampilan mereka ketidakpastian dalam penempatan karyawan bisa membuat karyawan bisa tidak maksimal dalam menyelesaikan tugasnya.

5. Perasaan aman dan masa depan

Semangat kerja akan tumbuh apabila para karyawan mempunyai perasaan aman terhadap masa depan profesi mereka, kestabilan perusahaan biasanya modal yang dapat diandalkan untuk menjamin rasa aman bagi para karyawan. Cara lain yang sering digunakan perusahaan yaitu mengadakan program pensiun.

6. Fasilitas yang memadai

Setiap perusahaan bila memungkinkan hendaknya menyediakan fasilitas yang memadai untuk karyawannya. Apabila perusahaan sanggup 
menyedialan fasilitas-fassilitas yang memadai, maka akan timbul rasa senang dalam bekerja.

Selain itu pengembangan karir dan promosi jabatan juga memiliki dampak sangat besar yang dapat mempertinggi semangat kerja karyawan. Menurut Manullang (2008:155) yang menyatakan bahwa : “Ada beberapa sebab mengapa di dalam setiap badan usaha perlu diambil tindakan promosi. Pertama-tama ialah untuk mempertinggi semangat kerja pegawainya. Bila mana promosi direalisasikan kepada mereka yang menghasilkan prestasi kerja yang tinggi, maka ada daya perangsang bagi para pegawai untuk mempertinggi semangat kerja'.

\subsubsection{Indikator Semangat Kerja}

Semangat kerja yang tinggi suatu kondisi yang sangat di harapkan oleh setiap organisasi. Untuk mengetahui apakah seseorang memiliki semangat kerja yang tinggi atau rendah maka dapat dilihat dari ciri-ciri yang terlibat dalam sikap sehari-hari. Adapun indikator untuk mengukur semangat kerja menurut (Nitisemito, 2010) indikator dari semangat kerja karyawan seperti berikut ini:

\section{Absensi}

Menunjukkan ketidakhadiran karyawan dari tugas atau kewajiban. Hal penting untuk memantau kehadiran karyawan.

2. Kerja sama 
Adalah keadaan dimana terdapat suasana bekerja secara bersama-sama yang selaras dan tetap untuk memperoleh kegunaan yang sebesarbesarnya dari faktor kerj

3. Kepuasan kerja

Kepuasan kerja sebagai keadaan emosional yang menyenangkan atau tidak menyenangkan dimana para karyawan memandang pekerjaan mereka.

\section{Kedisiplinan}

Adalah suatu sikap dan perilaku/perbuatan yang sesuai dengan aturan kantor, baik tertulis maupun tidak tertulis.

\subsubsection{Pengertian Pengembangan Karir}

“'Pengembangan karir adalah aktivitas kepegawaian yang membantu pegawai-pegawai merencanakan karir masa depan mereka diperusahaan agar perusahaan dan pegawai yang bersangkutan dapat mengembangkan diri secara maksimum", Mangkunegara (2011:77). Sedangkan menurut Rivai dan Sagala (2009:266) menjelaskan pengertian “pengembangan karir adalah proses peningkatan kemampuan kerja individu yang dicapai dalam rangka mencapai karir yang diinginkan'’.

Menurut (Kaseger,2013) pengembangan karir adalah suatu ancangan secara normal yang dapat digunakan perusahaan untuk dapat mengurus karyawan-karyawan yang ada dalam perusahaan yang memiliki kualifikasi diri, kemampuan, dan pengalaman yang sesuai saat dibutuhkan oleh perusahaan. Menurut (Regina, 2013) "pengembangan karir merupakan 
pendekatan formal yang dilakukan organisasi untuk menjamin orang-orang dalam organisasi mempunyai kualifikasi, kemampuan, dan pengalaman yang cocok ketika dibutuhkan', Dengan adanya kesempatan untuk melakukan pengembangan karir dengan kenaikan jabatan, maka hal ini akan memberikan semangat dalam bekerja bagi karyawan.

Menurut Wilson Bangun, (2018) “Pengembangan karier adalah serangkaian aktivitas yang mengarah pada penjajagan, dan pemantapan karir seseorang untuk mempemudah pencapaian tujuan karir di masa akan datang'.

Dari pengertian diatas, maka penulis dapat menyimpulkan bahwa pengembangan karir proses peningkatan kemampuan kerja individu yang dicapai dalam rangka mencapai karir yang diinginkan di masa yang akan datang, dan kenaikan posisi karyawan di perusahaan dalam jalur profesi yang sudah ditentukan agar karyawan lebih giat dan memiliki semangat kerja yang tinggi untuk memiliki karir yang lebih baik di perusahaan, sehingga perusahaan dan karyawan yang bersangkutan dapat mengembangkan diri secara maksimum untuk tujuan bersama.

\subsubsection{Faktor-Faktor Yang Mempengaruhi Pengembangan Karir}

Menurut Sondang P. Siagian (2006) faktor-faktor yang mempengaruhi pengembangan karir seorang karyawan adalah:

1. Prestasi Kerja 
Faktor yang paling penting untuk meningkatkan dan mengembangkan karir seseorang karyawan adalah pada prestasi kerjanya dalam melakukan tugas yang dipercayakan kepadanya. Tanpa prestasi kerja yang memuaskan, sukar bagi seorang pekerja untuk diusulkan oleh atasannya agar dipertimbangkan untuk dipromosikan ke pekerjaan atau jabatan yang lebih tinggi di masa depan

\section{Pengenalan Oleh Pihak Lain}

Pengenalan oleh pihak lain adalah berbagai pihak yang berwenang memutuskan layak tidaknya seseorang dipromosikan seperti atasan langsung dan pimpinan bagian kepegawaian yang mengetahui kemampuan dan prestasi kerja seorang pegawai.

3. Kesetiaan pada Organisasi

Kesetiaan pada organisasi merupakan dedikasi seorang karyawan yang ingin terus berkarya dalam organisasi tempatnya bekerja untuk jangka waktu yang lama.

4. Pembimbing dan Sponsor

Pembimbing adalah orang yang memberikan nasehat-nasehat atau saran-saran kepada karyawan dalam upaya mengembangkan karirnya. Sedangkan sponsor adalah seseorang di dalam institusi pendidikan yang dapat menciptakan kesempatan bagi karyawan untuk mengemabngkan kairirnya.

5. Dukungan para bawahan 
Dukungan para bawahan merupakan dukungan yang diberikan para bawahan dalam bentuk mensukseskan tugas manajer yang bersangkutan.

6. Kesempatan untuk Bertumbuh

Kesempatan untuk bertumbuh merupakan kesempatan yang diberikan kepada karyawan untuk meningkatkan kemampuannya, baik melalui pelatihan-pelatihan, kursus, dan juga melanjutkan jenjang pendidikannya.

\section{Pengunduran Diri}

Pengunduran diri merupakan keputusan seorang karyawan untuk berhenti bekerja dan beralih ke institusi pendidikan lain yang memberikan kesempatan lebih besar untuk mengembangkan karir.

Sedangkan menurut Siagian (2015), “'bahwa terdapat tujuh faktor yang mempengaruhi pengembangan karir pegawai, yaitu seperti prestasi kerja memuaskan, pengenalan oleh pihak lain, kesetiaan pada organisasi, pembimbing dan sponsor, dukungan para bawahan, kesempatan untuk bertumbuh, dan berhenti atas permintaan dan kemauan sendiri',

Untuk mengarahkan pengembangan karir agar menguntungkan perusahaan dan pegawai, maka pihak perusahaan harus mengadakan program-program pelatihan dan pengembangan karir yang dijalankan tergantung pada kebutuhan dan kebijakan masing-masing perusahaan. Pada umumnya perusahaan mengaplikasikan kegiatan pengembangan karir dalam bentuk pelatihan dan promosi. 


\subsubsection{Indikator Pengembangan Karir}

Adapun menurut Siagian (2015), berbagai indikator yang perlu dipertimbangkan dalam pengembangan karir adalah sebagai berikut:

1) Prestasi kerja memuaskan

Kegiatan dan hasil kerja yang dicapai atau ditunjukan oleh seseorang didalam pelaksanaan tugas pekerjaan. Tanpa prestasi kerja yang memuaskan, sulit bagi seorang pekerja untuk diusulkan oleh atasannya agar dipertimbangkan untuk dipromosikan ke pekerjaan atau jabatan yang lebih tinggi di masa depan.

2) Pengenalan oleh pihak lain

Berbagai pihak yang berwenang memutuskan layak tidaknya seseorang dipromosikan seperti atasan langsung dan pimpinan bagian kepegawaian yang mengetahui kemampuan dan prestasi kerja karyawan.

3) Kesetiaan pada organisasi

Merupakan dedikasi seorang karyawan yang ingin terus berkarya dalam organisasi tempatnya bekerja untuk jangka waktu yang lama.

4) Pembimbing dan Sponsor

Pembimbing adalah orang yang memberikan nasihat-nasihat atau saran-saran kepada karyawan dalam upaya mengembangkan karirnya. Sedangkan sponsor adalah seseorang di dalam perusahaan yang dapat menciptakan kesempatan bagi karyawan untuk mengembangkan karirnya. 
5) Dukungan dari bawahan

Merupakan dukungan yang diberikan para bawahan dalam bentuk mensukseskan tugas manajer yang bersangkutan.

6) Kesempatan untuk bertumbuh

Merupakan kesempatan yang diberikan kepada karyawan untuk meningkatkan kemampuannya, baik melalui pelatihan-pelatihan, kursus, dan juga melanjutkan jenjang pendidikannya.

\subsubsection{Tujuan dan Manfaat Pengembangan Karir}

Tujuan pengembangan karir adalah untuk meningkatkan efektivitas dan efisiensi pelaksanaan pekerjaan oleh karyawan agar memberikan hasil yang memuaskan untuk mencapai tujuan perusahaan dimana tempat ia bekerja. Menurut Mangkunegara (2013:77-78) tujuan pengembangan karir adalah:

1. Membantu dalam pencapaian tujuan individu dan perusahaan

2. Menunjukkan hubungan kesejahteraan karyawan

3. Membantu karyawan menyadari kemampuan potensi mereka

4. Memperkuat hubungan antara karyawan dan perusahaan

5. Membuktikan tanggung jawab social

6. Membantu memperkuat pelaksanaan program perusahaan

7. Mengurangi turn over dan biaya kekaryawanan

8. Mengurangi Keusangan profesi dan manajerial

9. Menggiatkan analisis dari keseluruhan karyawan

10. Menggiatkan suhu pemikiran jarak waktu yang panjang 
Menurut Handoko (2000) dalam (Shaputra \& Hendri, 2015) tujuan dari pengembangan karir adalah:

1. Untuk mengembangkan para pegawai agar dapat dipromosikan

2. Untuk mengungkapkan potensi pengawal

3. Untuk mendorong pertumbuhan

4. Untuk mengurangi penimbunan

5. Untuk memuaskan kebutuhan pegawai

6. Untuk meningkatkan karir

Manfaat pengembangan karir adalah untuk karyawan dan organisasi. Untuk karyawan, pengembangan karir yang didapatnya membuka kesempatan bagi dirinya untuk berkarya lebih baik dalam pekerjaannya. Untuk organisasi, manfaat yang diperolehnya yaitu peningkatan kinerja karyawannya dan banyak manfaat lain yang didapat organisasi tersebut.

Menurut Sri Widodo (2015:54) ada lima manfaat dalam pengembangan karir, yaitu:

1. Pengembangan karir memberi petunjuk siapa diantara para pekerja yang pantas untuk dipromosikan

2. Perhatian yang lebih besar dari bagian kepegawaian terhadap pengembangan karir menumbuhkan loyalitas di kalangan pegawai

3. Dalam diri setiap manusia masih terdapat reservoir kemampuan yang perlu di kembangkan agar berubah sifatnya dari potensi menjadi kekuatan nyata. 
4. Perencanaan karir mendorong para pekerja untuk bertumbuh dan berkembang, tidak hanya secara mental intelektuil, akan tetapi juga profesional

5. Perencanaan karir dapat meencegah terjadinya penumpukan tenagatenaga yang terhalang pengembangan karirnya.

Pengembangan karir akan memberikan manfaat bagi karyawan dan organisasi atau perusahaan itu sendiri berdasarkan tujuan-tujuan pengembangan yang telah ditentukan.

\subsubsection{Pengertian Promosi Jabatan}

Promosi jabatan ialah salah satu cara yang memiliki dampak sangat besar guna meningkatkan semangat kerja karyawan. Dengan adanya promosi jabatan, diharapkan semangat kerja karyawan meningkat dalam bekerja sehingga output yang dihasilkan berupa hasil kerj yang optimal akan semakin tercapai dalam mendorong kemajuan perusahaan dalam mencapai tujuannya dan berpengaruh positif bagi perusahaan,bilamana karyawan sudah memiliki semangat kerja yang tinggi.

"Promosi adalah apabila seseorang pegawai dipindahkan dari satu pekerjaan ke pekerjaan lain yang tanggung jawabnya lebih besar, tingkatnya dalam hirarki jabatan lebih tinggi dan penghasilannya pun lebih besar pula' Siagian (2010:169).

Sedangkan menurut Abdurrahmat Fathoni (2006:112) mengemukakan bahwa: "promosi atau orang sering menyebutnya kenaikkan jabatan/kedudukan dan pangkat atau status jenjang seorang 
pegawai, adalah merupakan peningkatan dari seorang tenaga kerja atau pegawai pada suatu tugas yang lebih baik, dibanding dengan sebelumnya dari sisi tanggung jawab yang lebih besar, prestasi, fasilitas, status yang lebih tinggi,tuntutan kecakapan yang lebih tinggi, dan adanya penambahan upah atau gaji, serta tunjangan lainnya'.

Siswanto Sastrohadiwiryo (2005:258) mendefiniskan bahwa “promosi dapat diartikan proses perubahan dari satu pekerjaan ke pekerjan lain dalam hierarki wewenang dan tanggung jawab yang lebih tinggi daripada dengan wewenang dan tanggung jawab yang telah diberikan kepada tenaga kerja pada waktu sebelumnya". Menurut Nitisemito (2008:81) " promosi adalah proses pemindahan karyawan dari satu jabatan ke jabatan lain yang lebih tinggi yang selalu diikuti oleh tugas, tanggung jawab dan wewenang yang lebih tinggi pula dari jabatan yang diduduki sebelumnya',

Menurut Hasibuan (2008:108) memberikan pengertian tentang “promosi jabatan yaitu promosi adalah perpindahan yang memperbesar authority (wewenang) dan responsibility (tanggung jawab) karyawan ke jabatan yang lebih tinggi di dalam organisasi sehingga kewajiban, hak, status, dan penghasilannya semakin besar'”.

Dari pernyataan-pernyataan diatas dapat disimpulkan bahwa promosi jabatan ditandai dengan adanya perubahan posisi ke tingkat yang lebih tinggi dalam hierarki wewenang dan tanggung jawab yang lebih tinggi daripada dengan wewenang dan tanggung jawab yang telah 
diberikan kepada tenaga kerja pada waktu sebelumnya. Sehingga kewajiban, tingkatan statusnya lebih tinggi dan penghasilannya pun lebih besar pula.

\subsubsection{Penetapan Kriteria Untuk Dipromosikan}

Menurut Siswanto Sastrohadiwiryo (2005:260) ada beberapa kriteria umum yang perlu dipertimbangkan dalam rangka mempromosikan tenaga kerja yaitu:

1. Senioritas

Tingkat senioritas tenaga kerja seringkali digunakan sebagai salah satu standar untuk kegiatan promosi. Dengan alasan lebih senior, pengalaman yang dimiliki pun dianggap lebi banyak daripada yang junior. Dengan demikian, diharapkan tenaga kerja yang bersangkutan memiliki kemampuan lebih tinggi, gagasan lebih banyk, dn kemampuan manajerial yang baik.

2. Kualifikasi Pendidikan

Saat ini, manajemen perusahaan umumnya mempunyai kriteria minimum tingkat pendidikan tenaga kerja yang bersangkutan untuk dapat dipromosikan pada jabatan tertentu. Alasan yang melatar belakanginya adalah dengan pendidikan yang lebih tinggi diharapkan tenga kerja memiliki memiliki daya nalar yang tinggi terhadap prospek perkembangan perusahaan di waktu mendatang.

3. Prestasi Kerja 
Hampir semua perusahaan menjadikan prestasi kerja yang dicapai tenaga kerj sebagai salah satu kriteria untuk kegiatan promosi. Prestasi kerja yang tinggi memilki kecendrungan untuk memperlancar kegiatan promosi bagi tenaga kerja yang bersangkutan, demikian pula kecendrungan sebaliknya.

4. Karsa dan Daya Cipta

Untuk kegiatan promosi pada jenis pekerjaan tertentu, barangkli karsa dan daya cipta merupakan salah satu syarat yang tidak perlu ditawar lagi. Hal ini disebabkan untuk jenis pekerjaan tertentu sangat memerlukan karsa dan daya cipta demi kelangsungan perusahaan. Dengan demikian, pelaksanaan promosi bagi tenaga keerja berdmpak pada meningkatnya laba yang tinggi daripada waktu sebelumnya.

5. Tingkat Loyalitas

Tingkat loyalitas tenaga kerja terhadap perusahaan seringkali menjadi salah satu kriteria untuk kegiatan promosi. Loyalitas yang tinggi akan berdampak pada tanggung jawab yang lebih besar.

6. Kejujuran

Khusus pada jabatan-jabatan yang berhubungan dengan finansial, produksi, pemasaran, dan sejenisnya, kejujuran dipandang amat penting. Hal ini dimaksud untuk menjaga jangan sampai kegiatan promosi malah merugikan perusahaan, karena ketidakjujuran tenaga kerja yang dipromosikan.

7. Supelitas 
Pada jenis pekerjaan/jabatan tertentu barangkali diperlukan kepandaian bergaul, sehingga kriteria kemampuan bergaul dengan orang lain perlu dijadikan salah satu standar untuk promosi pada pekerjaan/jabatan tersebut.

\subsubsection{Indikator Promosi Jabatan}

Setiap perusahaan memiliki pertimbangan yang berbeda-beda mengenai indikator-indikator yang diperhitungkan dalam proses promosi jabatan. Menurut Bambang Wahyudi (2011:173) sebagai berikut:

1. Kejujuran yang dimiliki

Kejujuran dipandang amat penting, hal ini dimaksud untuk menjaga jangan sampai kegiatan promosi malah merugikan perusahaan karena ketidakjujuran tenaga kerja yang dipromosikan.

2. Loyalitas

Tingkat loyalitas tenaga kerja terhadap perusahaan seringkali menjadi salah satu kriteria untuk kegiatan promosi. Loyalitas yang tinggi akan berdampak pada tanggung jawab yang lebih besar.

3. Tingkat Pendidikan/Prestasi Kerja

Saat ini, manajemen perusahaan umumnya mempunyai kriteria minimum tingkat pendidikan tenaga kerja yang bersangkutan untuk dapat dipromosikan pada jabatan tertentu. Alasan yang melatar belakanginya adalah dengan pendidikan yang lebih tinggi diharapkan tenga kerja memiliki memiliki daya nalar yang tinggi terhadap prospek perkembangan perusahaan di waktu mendatang. 
4. Pengalaman Kerj/Senioritas

Pengalaman kerja seringkali digunakan sebagai salah satu standar untuk kegiatan promosi. Dengan alasan lebih senior, pengalaman yang dimiliki pun dianggap lebi banyak daripada yang junior. Dengan demikian, diharapkan tenaga kerja yang bersangkutan memiliki kemampuan lebih tinggi, gagasan lebih banyk, dn kemampuan manajerial yang baik.

\subsubsection{Tujuan-Tujuan Promosi Jabatan}

Sebuah perusahaan memiliki tujuan yang berbeda-beda dalam menerapkan promosi untuk para pegawainya. Menurut Hasibuan (2012:113) mengemukakan tujuan umum diberikannya promosi, yaitu:

1) Untuk memberikan pengakuan, jabatan, dan imbalan jasa yang semakin besar kepada karyawan yang berprestasi kerrja tinggi

2) Dapat menimbulkan kepuasan dan kebanggaan pribadi, status sosial yang semakin tinggi, dan penghasilan yang semakin besar

3) Untuk merangsang agar karyawan lebih bergairah bekerja, berdisiplin tinggi, dan memperbesar produktivitas kerjanya.

4) Untuk menjamin stabilitas kepegawaian dengan direalisasinya promosi kepada karyawan dengan dasar pada waktu yang tepat serta penilaian yang jujur

5) Kesempatan promosi dapat menimbulkan keuntungan berantai dalam perusahaan karena timbulnya lowongan berantai 
6) Memberikan kesempatan kepada karyawan untuk mengembangkan kreativitas dan inovasinya yang lebih baik demi keuntungan optimal peerusahaan

7) Untuk menambah/memperluas pengetahuan serta pengalaman kerja para karyawan dan ini merupakan daya dorong bagi karyawan lainnya

8) Untuk mengisi kekosongan jabatan karena pejabatnya berhenti. Agar jabatan itu tidak lowong maka dipromosikan karyawan lainnya

9) Karyawan yang dipromosikan kepada jabatan yang tepat, semangat, kessenangan dan ketenanangan dalam bekerja semakin meningkat sehingga produktivitass kerjanya juga meningkat

10) Untuk mempermudah penarikan pelamar sebab dengan adanya kesempatan promosi merupakan daya pendorong serta perangsang bagi pelamar-pelamar untuk memasukan lamaranya

11) Promosi akan memperbaiki status karyawan dari karyawan sementara menjadi karyawan setelah lulus dalam masa percobaannya

\subsubsection{Jenis-jenis Promosi Jabatan}

Di setiap perusahaan menerapkan suatu jenis promosi yang berbedabeda untuk para karyawannya. Menurut Hasibuan (2012:113), mengemukakan beberapa jenis promosi yang dikenal luas saat ini, yaitu:

1. Promosi Sementara (Temporary promotion). Seorang karyawan dinaikkan jabatannya untuk sementara karena adanya jabatan yang lowong yang harus segera diisi, seperti pejabat dekan. 
2. Promosi Tetap (Permanent Promotion). Seorang karyawan dipromosikan dari suatu jabatan yang lebih tinggi karena karyawan tersebut telah memenuhi syarat untuk dipromosikan. Sifat promosi ini adalah tetap. Misalnya, seorang dosen dipromosikan menjadi dekan, wewenang, tanggung jawab, serta gajinya akan naik.

3. Promosi kecil (Small Scale Promotion). Menaikkan jabatan seseorang karyawan dari jabatan yang tidak sulit dipindahkan ke jabatan yang sulit meminta keterampilan tertentu,tetapi tidak disertai dengan peningkatan wewenang, tanggung jawab dan gaji.

4. Promosi Kering (Dry Promotion). Seorang karyawan dinaikkan jabatannya yang lebih tinggi disertai dengan peningkatan pangkat, wewenang dan tanggung jawab tetapi tidak disertai dengan kenaikan gaji atau upah.

\subsection{Pengaruh Antar Variabel}

\subsubsection{Pengaruh Pengembangan Karir $\left(X_{1}\right)$ Terhadap Semangat Kerja $(Y)$}

"Pengembangan karir aktivitas kepegawaian yang membantu pegawai-pegawai merencanakan karir masa depan mereka diperusahaan agar perusahaan dan pegawai yang bersangkutan dapat mengembangkan diri secara maksimum", Mangkunegara (2011:77). Semakain jelas pengembangan karir dalam suatu perusahaan akan meningkatkan semangat kerja karyawan karena merasa puas, dan meningkatnya loyalitas kerja. Adapun menurut Handoko (2000:123) 'Pengembangan karir adalah peningkatan-peningkatan pribadi yang dilakukan seseorang 
untuk mencapai suatu rencana karir', Kegiatan promosi jabatan perusahaan dapat memberikan harapan kepada karyawan untuk dapat lebih maju dari posisi yang dimilikinya, manusia yang bekerja di suatu perusahaan akan berusaha memperoleh kedudukan yang diinginkannya dengan harapan meningkatkan taraf hidup. Jadi pengembangan karir merupakan dorongan untuk maju dalam bekerja dengan baik artinya mengalami penigkatan yang akan membawa semangat kerja serta bekerja dengan maksimal. Pengaruh pengembangan karir terhadap semangat kerja karyawan juga pernah diteliti sebelumnya oleh Thoriq Rijalulloh Mochammad Al Musadieq dan Moehammad Soe'oed Hakam (2017) yang menyimpulkan "bahwa pengembangan karir berpengaruh positif signifikan terhadap semangat kerja'’

Penelitian terdahlu mengenai pengembangan karir juga dikemukakan oleh Esty Pudy Astuti dan Sipur (2019) dimana kesimpulannya "bahwa pengembangan karir berpengaruh positif terhadap semangat kerja'’.

\subsubsection{Pengaruh Promosi Jabatan $\left(\mathrm{X}_{2}\right)$ Terhadap Semangat Kerja (Y)}

Promosi jabatan juga memiliki dampak sangat besar yang dapat mempertinggi semangat kerja karyawan. Menurut Manullang (2008:155) yang menyatakan bahwa : "Ada beberapa sebab mengapa di dalam setiap badan usaha perlu diambil tindakan promosi. Pertama-tama ialah untuk mempertinggi semangat kerja pegawainya. Bila mana promosi direalisasikan kepada mereka yang menghasilkan prestasi kerja yang 
tinggi, maka ada daya perangsang bagi para pegawai untuk mempertinggi semangat kerja',

"Promosi jabatan adalah perpindahan yang memperbesar wewenang (authority) dan tanggung jawab (responsiblity) karyawan ke jabatan yang lebih tinggi di dalam satu organisasi sehingga kewajiban, hak, status, dan penghasilannya semakin besar', Hasibuan (2008:108). Apabila keinginan seseorang karyawan terpenuhi akan timbul suatu kepuasan dalam diri, sehingga menjadi pendorong semangat kerja bagi setiap karyawan.

Penelitian tentang promosi jabatan terhadap semangat kerja juga pernah diteliti sebelumnya, contoh penelitian yang dilakukan oleh Sinollah (2012), "hasil penelitian menunjukkan bahwa promosi jabatan berdampak besar dan signifikan terhadap semangat kerja karyawan'. Sehingga semakin jelas promosi jabatan suatu perusahaan maka semakin baik dan meningkatnya semangat kerja.

Penelitian lain mengenai promosi jabatan juga dilakukan oleh Abdi Setiawan (2018) “Hasil penelitian menunjukkan bahwa promosi jabatan dan lingkungan kerja secara parsial berpengaruh signifikan terhadap semangat kerja pegawai'’.

\subsubsection{Pengaruh Pengembangan Karir $\left(X_{1}\right)$ dan Promosi Jabatan $\left(X_{2}\right)$ Terhadap Semangat Kerja (Y)}

Hal yang paling penting dalam perusahaan yaitu pengelolaan sumber daya manusia, berupa manusia yang dipekerjakan di sebuah 
organisasi sebagai penggerak untuk mencapai tujuan organisasi itu. Hasil kerja yang baik akan dicapai apabila seluruh anggota organisasi mempunyai semangat kerja. Pengembangan karir ditujukan agar karyawan mempunyai kemampuan yang lebih tinggi dari kemampuan yang dimiliki sebelumnya sehingga dapat mengetahui fungsi dan peranan serta tanggung jawabnya di dalam pekerjaan. Dengan pengembangan karir juga diharapkan meningkatkan semangat kerja untuk kinerja yang lebih tinggi.

Perusahaan berusaha untuk menumbuhkan semangat kerja dimana dengan promosi jabatan disertai pengembangan karir maka hak dan kewajiban diatur sedemikian rupa selaras dengan fungsi, peranan dan tanggung jawab pegawai yang akan memenuhi keinginan karyawan yang dapat menimbulkan kepuasan dalam diri, sehingga dapat meningkatkan semangat kerja dan berpartisipasi dalam orgnisasi. Dalam mengukur semangat kerja karyawan dapat kita lihat dari kedisiplinan karyawan dalam bekerja. Menurut Bejo Siswanto Satrohadiwiryo (2002:291) bahwa "Disiplin kerja dapat didefinisikan sebagai suatu sikap menghormati, menghargai, patuh dan taat terhadap peraturan-peraturan yang berlaku, baik yang tertulis maupun tidak, serta sanggup menjalankannya dan tidak mengelak untuk menerima sanksi-sanksinya apabila ia melanggar tugas dan wewenang yang diberikan kepadanya'.

Banyak faktor yang membuat semangat kerja karyawan menurun, seperti yang dikatakan oleh Nurmansyah (2011:154) beberapa faktor 
yang dapat mempengaruhi rendahnya semangat kerja karyawan diantaranya:

1. Struktur organisasi yang kurang jelas, sehingga tugas dan tanggung jawab tumpang tindih

2. Desain pekerjaan kurang menarik

3. System kompensasi yang dirancang kurang memenuhi kebutuhan

4. kurangnya kesempatan pada karyawan untuk mengembangkan karir

Salah satu faktor rendahnya semangat kerja karyawan kurangnya kesempatan karyawan untuk mengembangkan karir, dan banyak cara untuk meningkatkan semangat kerja karyawan yaitu dengan adanya promosi jabatan. Menurut As'ad (2003:114) ada lima faktor yang menimbulkan semangat kerja, yaitu:

1. Kedudukan (Posisi)

2. Pangkat

3. Umur

4. Jaminan Finansial dan Jaminan Sosial

5. Mutu Pengawasan

Sehingga sangat penting di sebuah organisasi mengadakan pengembangan karir memberikan kedudukan atau adanya promosi jabatan untuk membuat karyawan meningkatkan semangat kerjanya. Karena begitu besar pengaruh pengembangan karir dan promosi jabatan terhadap semangat kerja karyawan itu sendiri. 
Adapun menurut Fadh (2005), dari hasil penelitian diketahui ‘bahwa pelaksanaan promosi jabatan mempunyai pengaruh besar dalam memotivasi karyawan untuk bekerja lebih giat lagi dan berprestasi'”.

Sedangkan menurut Thoriq Rijalulloh Mochammad Al Musadieq dan Moehammad Soe'oed Hakam (2017) yang menyimpulkan “bahwa pengembangan karir dan promosi jabatan berpengaruh signifikan terhadap semangat kerja karyawan'. Sehingga dapat disimpulkan semakin baik pengembangan karir dan promosi jabatan maka akan semakin tinggi semangat kerja karyawan.

Berdasarkan tinjaun teori di atas, bahwa pengembangan karir dan promosi jabatan mempengaruhi semangat kerja karyawan baik secara parsial maupun simultan.

\subsection{Hasil Penelitian Yang Relevan}

Penelitian-penelitian terdahulu berfungsi sebagai pendukung untuk melakukan penelitian. Adapun hasil-hasil penelitian yang dijadikan perbandingan tidak terlepas dari topik penelitian yaitu pengaruh pengembangan karir dan promosi jabatan terhadap semangat kerja.

Tabel 2.1

Penelitian Terdahulu

\begin{tabular}{|l|l|l|l|l|}
\hline No & $\begin{array}{c}\text { Judul Penelitian, } \\
\text { Peneliti dan Tahun } \\
\text { Penelitian }\end{array}$ & \multicolumn{1}{|c|}{$\begin{array}{c}\text { Hasil } \\
\text { Penelitian }\end{array}$} & Persamaan & Perbedaan \\
\hline 1 & $\begin{array}{l}\text { Pengaruh Kompetensi } \\
\text { dan Penempatan Kerja } \\
\text { Terhadap Semangat }\end{array}$ & $\begin{array}{l}\text { Hasil } \\
\text { penelitian } \\
\text { menunjukkan }\end{array}$ & $\begin{array}{l}\text { Terdapat } \\
\text { persamaan } \\
\text { dalam }\end{array}$ & $\begin{array}{l}\text { Dalam } \\
\text { penelitian } \\
\text { terdapat }\end{array}$ \\
\hline
\end{tabular}




\begin{tabular}{|c|c|c|c|c|}
\hline & $\begin{array}{l}\text { Kerja Karyawan PT. } \\
\text { Pertamina (Persero) } \\
\text { Refinery Unit III } \\
\text { Palembang } \\
\text { Siti Nurhasanah } \\
\text { Jurnal: Vol. 2, No.1 } \\
\text { (2015) }\end{array}$ & $\begin{array}{l}\text { bahwa } \\
\text { Kompetensi } \\
\text { dan } \\
\text { Penempatan } \\
\text { Kerja } \\
\text { berpengaruh } \\
\text { positif dan } \\
\text { signifikan } \\
\text { terhadap } \\
\text { semangat kerja } \\
\text { karyawan }\end{array}$ & $\begin{array}{l}\text { penelitian } \\
\text { mengenai } \\
\text { semangat kerja } \\
\text { sebagai } \\
\text { variabel } \\
\text { dependen }\end{array}$ & $\begin{array}{l}\text { perbedaan } \\
\text { pada } \\
\text { variabel } \\
\text { kompetensi } \\
\text { dan } \\
\text { penempatan } \\
\text { kerja }\end{array}$ \\
\hline 2 & $\begin{array}{l}\text { Analisis Pelaksanaan } \\
\text { Program Promosi } \\
\text { Jabatan Dampaknya } \\
\text { Terhadap Semangat } \\
\text { Kerja Karyawan Pada } \\
\text { UPTD pendidikan TK } \\
\text { Dan Sd Kec. Klemehan } \\
\text { Sinollah } \\
\text { Jurnal: Vol. } 12 \text { No. } 4 \\
\text { (2012) }\end{array}$ & $\begin{array}{l}\text { Hasil } \\
\text { penelitian } \\
\text { menunjukkan } \\
\text { bahwa } \\
\text { promosi } \\
\text { jabatan } \\
\text { berdampak } \\
\text { besar dan } \\
\text { signifikan } \\
\text { terhadap } \\
\text { semangat kerja } \\
\text { kerja } \\
\text { karyawan }\end{array}$ & $\begin{array}{l}\text { Terdapat } \\
\text { persamaan } \\
\text { dalam } \\
\text { penelitian } \\
\text { mengenai } \\
\text { promosi } \\
\text { jabatan sebagai } \\
\text { variabel } \\
\text { independen } \\
\text { dan semangat } \\
\text { kerja sebagai } \\
\text { variabel } \\
\text { dependen }\end{array}$ & $\begin{array}{l}\text { Dalam } \\
\text { penelitian } \\
\text { terdapat } \\
\text { perbedaan } \\
\text { metode } \\
\text { penelitian } \\
\text { menggunaka } \\
\text { n } \\
\text { pendekatan } \\
\text { penelitian } \\
\text { deskriptif } \\
\text { dan } \\
\text { verifikatif }\end{array}$ \\
\hline 3 & $\begin{array}{l}\text { Pengaruh Promosi } \\
\text { Jabatan Dan } \\
\text { Lingkungan Kerja } \\
\text { Terhadap Semangat } \\
\text { Kerja Pegawai Di } \\
\text { Lingkungan Universitas } \\
\text { Pembangunan } \\
\text { Pancabudi Medan } \\
\text { Abdi Setiawan } \\
\text { Jurnal: Vol. } 8 \text { No. } 2 \\
\text { (2018) }\end{array}$ & $\begin{array}{l}\text { Hasil } \\
\text { penelitian } \\
\text { menunjukkan } \\
\text { bahwa } \\
\text { promosi } \\
\text { jabatan dan } \\
\text { lingkungan } \\
\text { kerja secara } \\
\text { parsial } \\
\text { berpengaruh } \\
\text { signifikan } \\
\text { terhadap } \\
\text { semangat kerja } \\
\text { pegawai }\end{array}$ & $\begin{array}{l}\text { Terdapat } \\
\text { persamaan } \\
\text { dalam } \\
\text { penelitian } \\
\text { mengenai } \\
\text { promosi } \\
\text { jabatan sebagai } \\
\text { variabel } \\
\text { independen } \\
\text { dan semangat } \\
\text { kerja sebagai } \\
\text { variabel } \\
\text { dependen }\end{array}$ & $\begin{array}{l}\text { Dalam } \\
\text { penelitian } \\
\text { terdapat } \\
\text { perbedaan } \\
\text { pada } \\
\text { lingkungan } \\
\text { kerja } \\
\text { sebagai } \\
\text { variabel } \\
\text { independen }\end{array}$ \\
\hline
\end{tabular}




\begin{tabular}{|c|c|c|c|c|}
\hline 4 & $\begin{array}{l}\text { Pengaruh Budaya } \\
\text { Organisasi Dan } \\
\text { Pengembangan Karir } \\
\text { Terhadap Semangat } \\
\text { Kerja Karyawan Pada } \\
\text { PT. Sentosaraya Abadi } \\
\text { Mas } \\
\text { Esty Pudy Astuti dan } \\
\text { Sipur } \\
\text { Jurnal: Vol. XI No. } 1 \\
\text { (2019) }\end{array}$ & $\begin{array}{l}\text { Hasil } \\
\text { penelitian } \\
\text { menunjukkan } \\
\text { bahwa Budaya } \\
\text { organisasi dan } \\
\text { pengembangan } \\
\text { karir } \\
\text { berpengaruh } \\
\text { signifikan } \\
\text { terhadap } \\
\text { semangat kerja }\end{array}$ & $\begin{array}{l}\text { Terdapat } \\
\text { persamaan } \\
\text { dalam } \\
\text { penelitian } \\
\text { mengenai } \\
\text { pengembangan } \\
\text { karir sebagai } \\
\text { variabel } \\
\text { independen } \\
\text { dan semangat } \\
\text { kerja sebagai } \\
\text { variabel } \\
\text { dependen }\end{array}$ & $\begin{array}{l}\text { Dalam } \\
\text { penelitian } \\
\text { terdapat } \\
\text { perbedaan } \\
\text { pada Budaya } \\
\text { organisasi } \\
\text { sebagai } \\
\text { variabel } \\
\text { independen }\end{array}$ \\
\hline 5 & $\begin{array}{l}\text { Pengaruh Lingkungan } \\
\text { Kerja, Insentif, } \\
\text { Komunikasi dan } \\
\text { Senioritas terhadap } \\
\text { Semangat Kerja } \\
\text { Karyawan Ramayana } \\
\text { Departement Store } \\
\text { Cabang Kota } \\
\text { Tanjungpinang } \\
\text { Eko Murtisaputra } \\
\text { Sri langgeng Ratnasari } \\
\text { Jurnal: Vol. } 7 \text { No. } 3 \\
\text { (2018) }\end{array}$ & $\begin{array}{l}\text { Hasil } \\
\text { penelitian } \\
\text { menunjukkan } \\
\text { bahwa } \\
\text { Lingkungan } \\
\text { Kerja, Insentif, } \\
\text { Komunikasi } \\
\text { dan Senioritas } \\
\text { berpengaruh } \\
\text { signifikan } \\
\text { terhadap } \\
\text { semangat kerja } \\
\text { karyawan }\end{array}$ & $\begin{array}{l}\text { Keduanya } \\
\text { sama-sama } \\
\text { membahas } \\
\text { tentang } \\
\text { semangat kerja }\end{array}$ & $\begin{array}{l}\text { Perbedaanny } \\
\text { a terletak } \\
\text { pada } \\
\text { Variabel } \\
\text { independen }\end{array}$ \\
\hline 6 & $\begin{array}{l}\text { The influence of } \\
\text { Training, Competence } \\
\text { and Motivation, to the } \\
\text { Working Spirits } \\
\text { Moderated By Internal } \\
\text { Communications }\end{array}$ & $\begin{array}{l}\text { Hasil } \\
\text { penelitian } \\
\text { menunjukkan } \\
\text { bahwa } \\
\text { pelatihan, } \\
\text { kompetensi } \\
\text { dan motivasi } \\
\text { berpengaruh }\end{array}$ & $\begin{array}{l}\text { Kedua } \\
\text { penelitian } \\
\text { membahas } \\
\text { tentang } \\
\text { Semangat } \\
\text { Kerja }\end{array}$ & $\begin{array}{l}\text { Dalam } \\
\text { penelitian } \\
\text { terdapat } \\
\text { perbedaan } \\
\text { pada } \\
\text { variabel } \\
\text { kompetensi } \\
\text { dan motivasi }\end{array}$ \\
\hline
\end{tabular}




\begin{tabular}{|c|c|c|c|c|}
\hline & $\begin{array}{l}\text { Subari dan Hanes Riady } \\
\text { Jurnal Internasional } \\
\text { Vol. 1, Issue } 2 \\
\text { ISSN: } 3185-3275 \\
(2015)\end{array}$ & $\begin{array}{l}\text { positif dan } \\
\text { signifikan } \\
\text { terhadap } \\
\text { semangat kerja }\end{array}$ & & \\
\hline \multirow[t]{2}{*}{7} & $\begin{array}{l}\text { Pengaruh Fasilitas dan } \\
\text { Lingkungan Kerja } \\
\text { Terhadap Semangat } \\
\text { Kerja Karyawan Pada } \\
\text { BANK SUMUT- } \\
\text { MEDAN }\end{array}$ & $\begin{array}{l}\text { Hasil } \\
\text { penelitian } \\
\text { menunjukkan } \\
\text { bahwa fasilitas } \\
\text { kerja dan } \\
\text { lingkungan } \\
\text { kerja secara }\end{array}$ & $\begin{array}{l}\text { Kedua } \\
\text { penelitian } \\
\text { membahas } \\
\text { tentang } \\
\text { Semangat Kerja } \\
\text { yaitu sebagai } \\
\text { variabel }\end{array}$ & $\begin{array}{l}\text { Dalam } \\
\text { penelitian } \\
\text { ini terdapat } \\
\text { perbedaan } \\
\text { pada } \\
\text { variabel } \\
\text { Independen }\end{array}$ \\
\hline & $\begin{array}{l}\text { Bakhtiar } \\
\text { Jurnal: Vol. 2. No. } 3 \\
\text { (2017) }\end{array}$ & $\begin{array}{l}\text { bersama-sama } \\
\text { mempunyai } \\
\text { pengaruh yang } \\
\text { signifikan } \\
\text { terhadap } \\
\text { semangat kerja } \\
\text { karyawan di } \\
\text { PT. Bank } \\
\text { Sumut Medan }\end{array}$ & dependen & \\
\hline 8 & $\begin{array}{l}\text { Pengaruh } \\
\text { Pengembangan Karir } \\
\text { dan Promosi Jabatan } \\
\text { Terhadap Semangat } \\
\text { Kerja Studi Pada } \\
\text { Karyawan Perusahaan } \\
\text { Daerah Air Minum } \\
\text { Kota Malang } \\
\text { Thoriq Rijalulloh, dkk } \\
\text { Jurnal: Vol.51 No.2 } \\
\text { (2017) }\end{array}$ & $\begin{array}{l}\text { Hasil } \\
\text { penelitian } \\
\text { menunjukkan } \\
\text { Pengembangan } \\
\text { Karir Dan } \\
\text { Promosi } \\
\text { Jabatan } \\
\text { berpengaruh } \\
\text { signifikan } \\
\text { terhadap } \\
\text { semangat kerja } \\
\text { karyawan }\end{array}$ & $\begin{array}{l}\text { Kedua } \\
\text { penelitian ini } \\
\text { membahas } \\
\text { tentang } \\
\text { Semangat Kerja } \\
\text { yaitu sebagai } \\
\text { variabel } \\
\text { dependen }\end{array}$ & $\begin{array}{l}\text { Dalam } \\
\text { penelitian } \\
\text { terdahulu } \\
\text { menggunak } \\
\text { an metode } \\
\text { penelitian } \\
\text { kualitatif } \\
\text { sedangkan } \\
\text { penelitian } \\
\text { ini } \\
\text { menggunak } \\
\text { an jenis } \\
\text { penelitian } \\
\text { kuantitatif }\end{array}$ \\
\hline
\end{tabular}




\begin{tabular}{|c|c|c|c|c|}
\hline 9 & $\begin{array}{l}\text { Pengaruh Komunikasi } \\
\text { dan Lingkungan Kerja } \\
\text { Terhadap Semangat } \\
\text { Kerja Karyaywan Pada } \\
\text { PT. Gita Riau Makmur } \\
\text { Pekanbaru }\end{array}$ & $\begin{array}{l}\text { Hasil } \\
\text { penelitian } \\
\text { menunjukkan } \\
\text { bahwa } \\
\text { Komunikasi } \\
\text { dan } \\
\text { Lingkungan } \\
\text { Kerja } \\
\text { mempunyai } \\
\text { pengaruh } \\
\text { positif } \\
\text { terhadap } \\
\text { Semangat } \\
\text { Kerja }\end{array}$ & $\begin{array}{l}\text { Kedua } \\
\text { penelitian ini } \\
\text { membahas } \\
\text { tentang } \\
\text { Semangat Kerja } \\
\text { yaitu sebagai } \\
\text { variabel } \\
\text { dependen }\end{array}$ & $\begin{array}{l}\text { Dalam } \\
\text { penelitian } \\
\text { ini terdapat } \\
\text { perbedaan } \\
\text { pada } \\
\text { Variabel } \\
\text { Komunikasi } \\
\text { dan } \\
\text { Lingkungan } \\
\text { Kerja } \\
\text { sebagai } \\
\text { independen }\end{array}$ \\
\hline
\end{tabular}

Berdasarkan berbagai penelitian di atas, dapat disimpulkan bahwa penelitian yang dilakukan penulis tidak sama persis dengan penelitian yang telah ada, Penelitian yang dilakukan peneliti terdahulu menunjukkan bahwa semangat kerja dipengaruhi oleh pengembangan karir dan promosi jabatan. Persamaan penelitian ini adalah sama-sama meneliti semangat kerja. Perbedaannya adalah tempat dan waktu penelitian serta variabel independent yang diteliti.

\subsection{Kerangka Berpikir}

Uma Sekaran dalam bukunya Business Research, 1992 dalam (Sugiyono, 2010) “mengemukakan bahwa, kerangka pemikiran merupakan model konseptual tentang bagaimana teori berhubungan dengan berbagai faktor yang telah diidentifikasi sebagai masalah yang penting'. 
Secara sederhana kerangka pemikiran tersebut tergambar dalam bagan alur pikir dibawah ini:

Gambar 2.1 Kerangka Berpikir

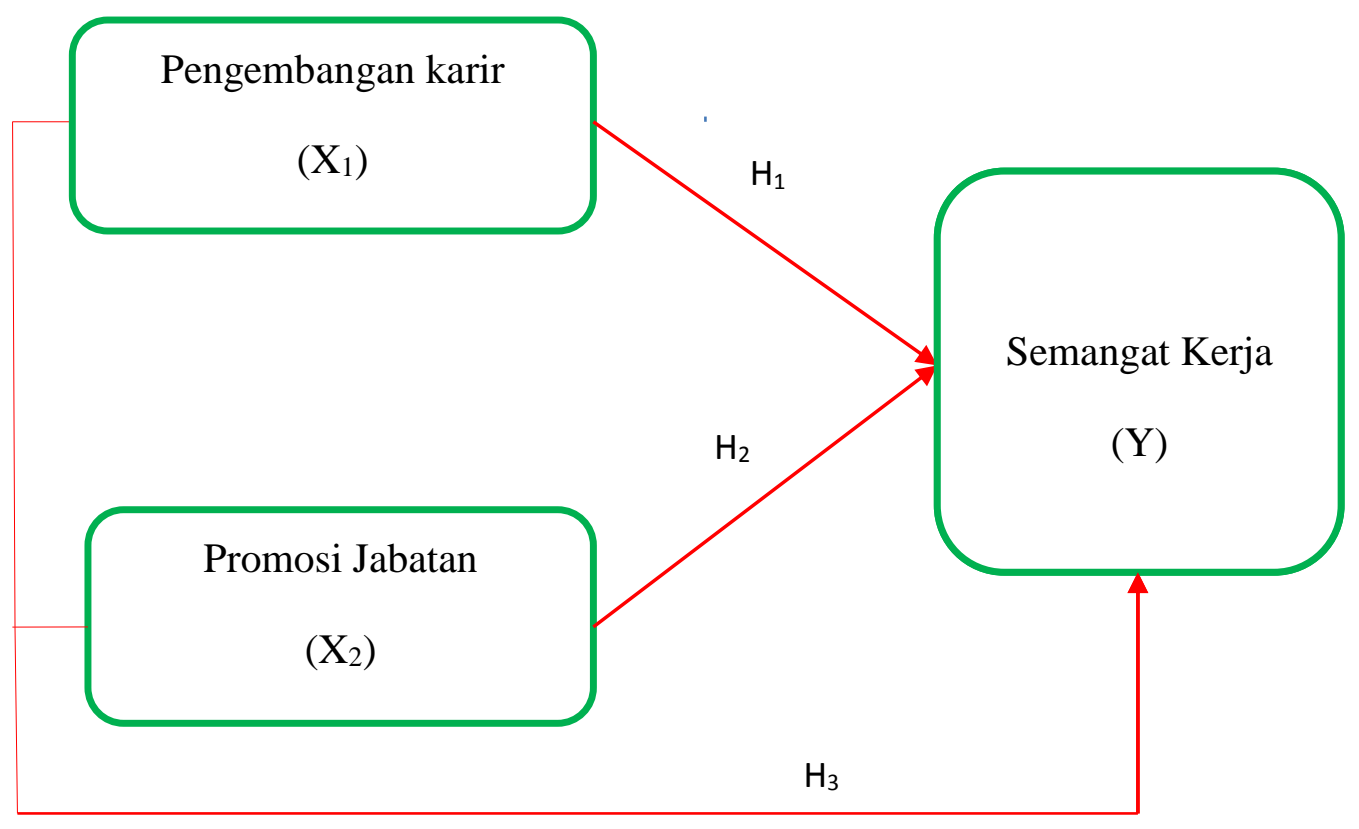

Keterangan:

$\mathrm{X}_{1}$ : Pengembangan Karir

$\mathrm{X}_{2}$ : Promosi Jabatan

Y : Semangat Kerja 


\subsection{Definisi Operasional}

Tabel 2.2

Definisi Operasional

\begin{tabular}{|c|c|c|c|c|}
\hline No & Variabel & Indikator & Alat Ukur & Skala \\
\hline 1 & $\begin{array}{l}\text { Pengembangan Karir } \\
\left(\mathrm{X}_{1}\right) \\
\text { Pengembangan karir } \\
\text { proses peningkatan } \\
\text { kemampuan kerja } \\
\text { individu yang dicapai } \\
\text { dalam rangka mencapai } \\
\text { karir yang diinginkan di } \\
\text { masa yang akan datang, } \\
\text { dan kenaikan posisi } \\
\text { karyawan di perusahaan } \\
\text { dalam jalur profesi } \\
\text { yang sudah ditentukan } \\
\text { agar karyawan lebih } \\
\text { giat dan memiliki } \\
\text { semangat kerja yang } \\
\text { tinggi untuk memiliki } \\
\text { karir yang lebih baik di } \\
\text { perusahaan }\end{array}$ & $\begin{array}{l}\text { 1. Prestasi kerja } \\
\text { memuaskan } \\
\text { 2. Pengenalan oleh pihak } \\
\text { lain } \\
\text { 3. Kesetiaan pada } \\
\text { organisasi } \\
\text { 4. Pembimbing dan } \\
\text { Sponsor } \\
\text { 5. Dukungan para } \\
\text { bawahan } \\
\text { 6. Kesempatan untuk } \\
\text { bertumbuh } \\
\text { Siagian (2015) }\end{array}$ & Kuesioner & Ordinal \\
\hline 2 & $\begin{array}{l}\text { Promosi Jabatan }\left(\mathrm{X}_{2}\right) \\
\text { Promosi jabatan adalah } \\
\text { ditandai dengan adanya } \\
\text { perubahan posisi ke } \\
\text { tingkat yang lebih } \\
\text { tinggi dalam hierarki } \\
\text { wewenang dan } \\
\text { tanggung jawab yang } \\
\text { lebih tinggi daripada } \\
\text { dengan wewenang dan } \\
\text { tanggung jawab yang } \\
\text { telah diberikan kepada }\end{array}$ & $\begin{array}{l}\text { 1) Kejujuran yang } \\
\text { dimiliki } \\
\text { 2) Loyalitas } \\
\text { 3) Tingkat } \\
\text { pendidikan/Prestasi } \\
\text { kerja } \\
\text { 4) Penglaman } \\
\text { Kerja/Senioritas } \\
\text { Bambang Wahyudi } \\
\text { (2011:173) }\end{array}$ & Kuesioner & Ordinal \\
\hline
\end{tabular}




\begin{tabular}{|c|c|c|c|c|}
\hline & $\begin{array}{l}\text { tenaga kerja pada waktu } \\
\text { sebelumnya sehingga } \\
\text { kewajiban, tingkatan } \\
\text { statusnya lebih tinggi } \\
\text { dan penghasilannya pun } \\
\text { lebih besar pula. }\end{array}$ & & & \\
\hline 3 & $\begin{array}{l}\text { Semangat Kerja (Y) } \\
\text { Semangat kerja } \\
\text { merupakan gambaran } \\
\text { perasaan seseorang } \\
\text { yang mempunyai } \\
\text { keinginan dan } \\
\text { kesungguhan memiliki } \\
\text { kedisiplinan untuk } \\
\text { mencapai prestasi kerja } \\
\text { yang maksimal dan } \\
\text { menunjukkan rasa } \\
\text { kegairahan di dalam } \\
\text { melaksanakan } \\
\text { pekerjaan dan } \\
\text { mendorong mereka } \\
\text { untuk bekerja secara } \\
\text { lebih baik dan lebih } \\
\text { produktif }\end{array}$ & $\begin{array}{l}\text { 1) Absensi } \\
\text { 2) Kerja sama } \\
\text { 3) Kepuasan Kerja } \\
\text { 4) Kedisiplinan } \\
\text { (Nitisemito, 2010) }\end{array}$ & Kuesioner & Ordinal \\
\hline
\end{tabular}

\subsection{Hipotesis}

Hipotesis ialah dugaan sementara, yang masih perlu dibuktikan kebenarannya dengan penelitian lebih lanjut. Menurut zikmud (2003) hipotesis merupakan proposi atau dugaan yang belum terbukti yang secara tentatif menerangkan fakta-fakta atau fenomena tertentu dan juga merupakan jaawaban yang memungkinkan terhapat suatu pertanyaan riset. 
Berdasarkan kajian teoritis, penelitian sebelumnya, dan tujuan dari penelitian maka hipotesis yang dapat diajukan dalam penelitian ini adalah sebagai berikut :

1. H1 : Terdapat Pengaruh Pengembangan Karir yang signifikan Terhadap Semangat Kerja Karyawan PDAM Kota Bengkulu

2. $\mathbf{H}_{2}$ : Terdapat Pengaruh Promosi Jabatan yang signifikan Terhadap Semangat Kerja Karyawan PDAM Kota Bengkulu

3. H3 : Terdapat Pengaruh Pengembangan Karir dan Promosi Jabatan yang signifikan Terhadap Semangat Kerja Karyawan PDAM Kota Bengkulu

\section{BAB III \\ METODE PENELITIAN}

\subsection{Tempat dan Waktu Penelitian}

Lokasi penelitian di PDAM Kota Bengkulu, Jl. Hibrida XV No.81, Sidomulyo, Kec. Gading Cempaka, Kota Bengkulu. Yang menjadi objek ialah karyawan PDAM Kota Bengkulu, terkait dengan Pengaruh Pengembangan Karir dan Promosi Jabatan Terhadap Semangat Kerja Karyawan PDAM Kota Bengkulu. Penelitian mengambil lokasi ini dikarenakan melihat masih rendahnya semangat kerja karyawan PDAM Kota Bengkulu. Sehingga peneliti tertarik untuk mengadakan penelitian di PDAM Kota Bengkulu. 
Penelitian ini akan dilaksanakan selama kurang lebih 1 bulan, yaitu mulai akhir Januari sampai Februari 2020. Penelitian terhitung hingga terselesaikannya proposal ini.

\subsection{Metode Penelitian}

Penelitian yang digunakan dalam penelitian ini adalah penelitian Kuantitatif. Penelitian Kuantitatif Penelitian yang menyatakan hubungan asosiasif, menurut Sugiyonoo (2012:11), "penelitian asosiatif merupakan penelitian yang bertujuan untuk mengetahui pengaruh variabel terikat dan seberapa eratnya pengaruh atau hubungan itu serta berarti atau tidaknya pengaruh atau hubungan itu'. Dalam penelitian ini menggunakan metode survei.

Penelitian ini menggunakan teknik korelasional, "Korelasional adalah suatu penelitian untuk mengetahui hubungan dan tingkat hubungan antara dua variabel atau lebih tanpa ada upaya untuk mempengaruhi variabel tersebut sehingga tidak terdapat manipulasi variabel', (Faenkel dan Wallen, 2008:328). Variabel terikat adalah Semangat Kerja (Y) dan Variabel bebas adalah Pengembangan Karir $\left(\mathrm{X}_{1}\right)$, dan Promosi Jabatan $\left(\mathrm{X}_{2}\right)$.

\subsection{Populasi dan Sampel}

\subsubsection{Populasi}

Menurut Sugiyono (2014:115), populasi adalah generalisasi yang terdiri atas subjek atau objek yang mempunyai kualitas dan karakteristik tertentu yang diterapkan oleh peneliti untuk dipelajari dan kemudian ditarik kesimpulannya. 
Populasi dalam penelitian ini adalah seluruh karyawan tetap Perusahaan Daerah Air Minum Kota Bengkulu, yang berjumlah 136 orang.

\subsubsection{Sampel}

Menurut Sugiyono (2016:85) sampel adalah bagian dari jumlah karakteristik yang dimiliki oleh populasi tersebut. Untuk sampel yang diambil dari populasi harus betul-betul representative (mewakili). Jika dilihat dari jumlah populasi yang ada yaitu 136 orang maka peneliti menggunakan seluruh populasi yang ada, dengan menggunakan teknik sampling jenuh, istilah lain sampel jenuh adalah sensus dimana semua anggota populasi dijadikan sampel. Sampel yang seharusnya 136 menjadi 130 sampel hal ini dikarenakan berbagai hambatan yang ditemukan di lapangan yaitu:

1) 2 orang karyawan yang sedang cuti

2) 3 orang karyawan yang tidak bersedia menjadi responden

3) 1 orang karyawan yang sedang dinas di luar kota

\subsection{Teknik Pengumpulan Data}

Metode pengumpulan data dalam penelitian ini yang tepat, dengan mempertimbangkan penggunaannya berdasarkan jenis data dan sumbernya. Data yang obyektif dan relevan dengan pokok permasalahan penelitian ialah indikator keberhasilahan suatu penelitian. Dalam penelitian ini pengumpulan data dilakukan dengan cara pengisian kuesioner dan observasi untuk memperoleh data primer, sesuai dengan 
tujuan penelitian. Dimana peneliti menemui responden secara langsung, tentunya dengan peraturan dan tidak mengganggu proses kerja diperusahaan. Metode yang digunakan peneliti dalam pengumpulan data adalah.

\section{Observasi}

“Teknik observasi digunakan untuk melihat dan mengamati perubahan fenomena-fenomena sosial yang tumbuh dan berkembang yang kemudian dapat dilakukan perubahan atas penilaian tersebut, bagi pelaksanaan observasi untuk melihat obyek moment tertentu, sehingga mampu memisahkan antara yang diperlukan dengan yang tidak diperlukan', (Margono, 2007:159).

Sehingga dalam penelitian ini Observasi digunakan untuk melihat dan mengamati perubahan fenomena-fenomena sosial yang tumbuh dan berkembang serta untuk melihat obyek moment tertentu yang ada di Perusahaan Daerah Air Minum Kota Bengkulu dengan permasalahan yang ada, dan mampu memisahkan antara yang diperlukan dengan yang tidak diperlukan dalam penelitian ini.

\section{Kuesioner}

Menurut Sugiyono (2013 : 142) “Kuesioner merupakan teknik pengumpulan data yang dilakukan dengan cara memberi seperangkat pertanyaan atau pernyataan tertulis kepada responden untuk dijawabnya'. Kuesioner dalam penelitian ini salah satu teknik pengumpulan data yang digunakan untuk mendapatkan jawaban dari responden terkait dengan 
variabel pengembangan karir, promosi jabatan dan semangat kerja sehingga peneliti dapat melakukan pengumpulan data dari skor jawaban yang diberikan responden melalui pertanyaan atau pernyataan yang telah diberikan.

Teknik pengukuran skor atau nilai yang digunakan dalam penelitian ini ialah memakai skala ordinal. Sebagai alat untuk mengukur jawaban, sikap, pendapat, dan persepsi seseorang atau sekelompok orang tentang variabel-variabel yang akan diuji dan pada setiap jawaban akan diberi skor. "Alternatif penilaian dalam pengukuran item-item tersbut terdiri dari 5 (lima) alternatif pilihan yang mempunyai tingkatan sangat rendah sampai dengan sangat tinggi (bernilai 1 s/d 5) yang diterapkan secara bervariasi sesuai pertanyaan”'(Ghozali, 2011, Asmawi, M., 2017). Penentu skor dari yang setiap pertanyaan dengan alternatif jawaban yang berbeda, yaitu:

1) Jawaban "Sangat Setuju" diberi nilai 5.

2) Jawaban "Setuju” diberi nilai 4.

3) Jawaban "Kurang Setuju”, diberi nilai 3.

4) Jawaban "Tidak Setuju" diberi nilai 2.

5) Jawaban "Sangat Tidak Setuju” diberi nilai 1.

Tabel 3.1

Kisi - Kisi Kuesioner

\begin{tabular}{|l|l|l|c|c|}
\hline No & \multicolumn{1}{|c|}{ Variabel } & \multicolumn{1}{|c|}{ Indikator } & $\begin{array}{c}\text { Butir } \\
\text { Kuesioner }\end{array}$ & Jumlah \\
\hline 1 & $\begin{array}{l}\text { Pengembangan } \\
\text { Karir }\left(\mathrm{X}_{1}\right)\end{array}$ & $\begin{array}{l}\text { 1) } \\
\begin{array}{l}\text { Prestasi kerja } \\
\text { memuaskan }\end{array}\end{array}$ & $1-2$ & 2 \\
\hline
\end{tabular}




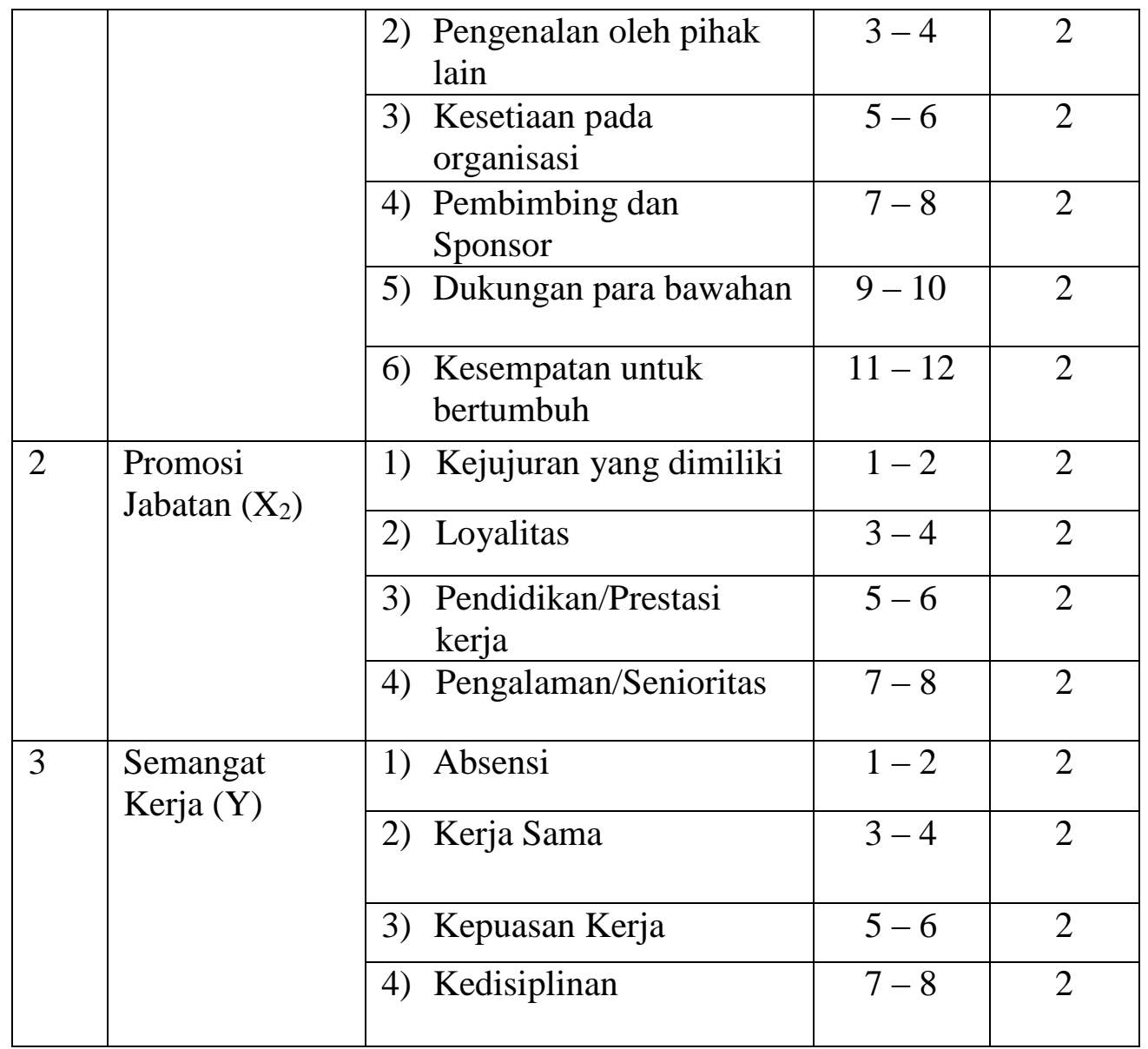

\subsection{Uji Instrumen Penelitian}

\subsubsection{Uji Validitas}

Ghozali (2013:52) mendeskripsikan bahwa uji validitas digunakan untuk mengukur valid atau tidaknya suatu kuesioner. Menurut Onsardi (2018) Baik buruknya instrumen penelitian ditunjukkan oleh tingkat kesahihan (validity) dan keandalan (reliability). Suatu instrumen dapat dinyatakan valid jika setiap pertanyaannya mampu untuk mengungkapkan sesuatu yang diukur instrumen tersebut. Validitas menunujukkan sejauh mana ketepatan dan kecermatan suatu alat ukur dalam melakukan fungsi ukurnya. Pengujian validitas membutuhkan bantuan penggunaan program 
IBM SPSS 22. Validitas sebuah item pertanyaan indikator dapat dilihat dalam output nilai sig hitung (2tailed) pearson correalation pada baris total konstruk. Data dapat dikatakan valid jika nilai sig hitung < sig table. Dalam penelitian ini menggunakan standart significance $5 \%$ pada $r$ tabel .

\subsubsection{Uji Reliabilitas}

Ghozali (2013:47) menyatakan reliabilitas adalah alat ukur suatu kuesioner yang merupakan indikator dari variabel atau konstruk. Suatu kuesioner dikatakan reliabel atau handal jika jawaban seseorang terhadap pertanyaan menunjukan kekonsistenan atau stabil dari waktu kewaktu. Untuk menguji reliabilitas instrumen dapat menggunakan teknik Cronbach alpha dengan bantuan IBM SPSS 22. Suatu konstruk atau variabel dikatakan realibel jika memberikan nilai Cronbach alpha> 0.60 (Nunnally, 1994 dalam Ghozali, 2013:47). Dalam penelitian ini pengukuran menggunakan bantuan IBM SPSS 22 dalam menguji validitas dan reliabilitas instrumen kuesioner. Pengukuran reliabilitas menggunakan One Shot atau pengukuran sekali saja yaitu pengukurannya hanya dilakukan sekali yang kemudian hasilnya dibandingkan dengan pertanyaan lain atau mengukur korelasi antar jawaban pertanyaan.

\subsection{Teknik Analisis Data}

Adapun tahapan teknik analisis data yang dilakukan pada penelitian ini adalah sebagai berikut: 


\subsubsection{Analisis Deskriptif}

Analisis Deskriptif ialah suatu analisis yang digunakan untuk menguraikan tanggapan responden mengenai pengaruh pengembangan karir dan promosi jabatan terhadap semangat kerja karyawan dengan menyebarkan kuesioner kepada karyawan tetap, di Perusahaan Daerah Air Minum Kota Bengkulu yang menjadi sampel dalam penelitian ini.

"Analisis deskriptif digunakan memberikan gambaran atau deskripsi suatu data yang teliti. Dalam menggunakan statistik deskriptif, suatu data dapat dilihat dari nilai rata-rata, standar deviasi, varian, maksimum, minimum, sum, range, kurtosis dan skewness. Statistik deskriptif digunakan untuk mempermudah ciri-ciri karakteristik suatu kelompok data agar mudah dipahami' Ghozali (2013:19). Digunakan rumus:

$$
\text { Mean }=\frac{\sum f X}{N}
$$

Dimana :

$\mathrm{F} \quad=$ Frekuensi jawaban responden

$\mathrm{X}=$ Skor jawaban responden

$\mathrm{N}=$ Jumlah sample

Selanjutnya, dihitung juga skala interval jawaban responden, yang bertujuan untuk memudahkan interprestasi hasil dengan rumus

$$
\text { Skala Interval }=\frac{U-L}{k}
$$


Dimana :

$\mathrm{U}=$ Skor jawaban tertinggi

$\mathrm{L}=$ Skor jawaban terendah

$\mathrm{K}=$ Jumlah kelas interval

Dari rumus diatas, maka skala interval yang digunakan dalam

penelitian ini adalah sebagai berikut:

Dik :

Skor jawaban tertinggi $(\mathrm{U})=5$

Skor jawaban terendah $(\mathrm{L})=1$

Jumlah kelas interval $(\mathrm{k})=5$

Skala interval $=\frac{5-1}{5}=\frac{4}{5}=0,80$

Jadi jarak (skala) setiap kelas interval sebesar 0,80

Dari skala interval tersebut, selanjutnya diinter kinerjakan ke dalam rata-rata jawaban responden dengan kriteria:

TABEL 3.2

\begin{tabular}{|c|c|}
\hline $4,21-5,00$ & Sangat baik \\
\hline $3,41-4,20$ & Baik \\
\hline $2,61-3,40$ & Cukup Baik \\
\hline $1,81-2,60$ & Kurang Baik \\
\hline $1,00-1,80$ & Tidak Baik \\
\hline
\end{tabular}




\subsubsection{Regresi Linier Berganda}

Analisis regresi linier berganda adalah hubungan secara linear antara dua atau lebih variabel independen (X1, X2,...Xn) dengan variabel dependen $(\mathrm{Y})$. Analisis regresi merupakan metode analisis yang tepat ketika penelitian melibatkan satu variabel terikat yang diperkirakan berhubungan dengan satu atau lebih variabel bebas, (Ghozali, 2011). Penelitian ini bertujuan untuk mengetahui pengaruh variabel bebas yaitu Pengembangan Karir $\left(\mathrm{X}_{1}\right)$, dan Promosi Jabatan $\left(\mathrm{X}_{2}\right)$ terhadap Semangat $\operatorname{Kerja~(Y).~}$

Berdasarkan uraian diatas maka penulis memutuskan untuk menggunakan analisis regresi linear berganda untuk menguji hipotesis yang ada, selain itu juga merujuk dari sebagian penelitian terdahulu yang juga menggunakan analisis regresi linear berganda sebagai metode uji hipotesisnya. Adapun bentuk persamaan regresi linier berganda adalah sebagai berikut:

$$
Y=a+b 1 X_{1}+b 2 X_{2}+e
$$

Keterangan:

Y : Semangat Kerja

a : Intercept (konstanta)

b1 : Koefisien regresi untuk $\mathrm{X}_{1}$

b2 : Koefisien regresi untuk $\mathrm{X}_{2}$

$\mathrm{X}_{1}$ : Pengembangan Karir

$\mathrm{X}_{2}$ : Promosi Jabatan

e : Nilai residu 


\subsubsection{Koefisien Determinasi $\left(\mathbf{R}^{2}\right)$}

Koefisien Determinasi $\left(\mathrm{R}^{2}\right)$ pada intinya mengukur seberapa jauh kemampuan model dalam menerangkan variasi variabel independen.Nilai koefisien determinasi adalah antara nol dan satu. Nilai $\mathrm{R}^{2}$ yang kecil berarti kemampuan variabel-variabel independen dalam menjelaskan variasi variabel dependen sangat terbatas. Nilai yang mendekati satu berarti variabel-variabel independen memberikan hampir semua informasi yang dibutuhkan untuk memprediksi variabel-variabel dependen (Ghozali, 2006).

Dengan Rumus :

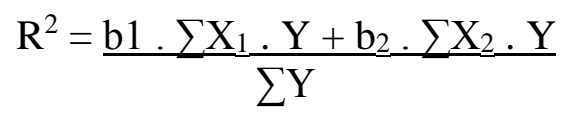

Keterangan :

$\mathrm{R}^{2}=$ Koefisien determinasi berganda

$\mathrm{Y}=$ Variabel terikat (dependent)

$\mathrm{X}=$ Variabel bebas (Independent)

\subsection{Uji Asumsi Klasik}

Sebelum melakukan pengujian hipotesis, terlebih dahulu akan dilakukan pengujian terjadinya penyimpangan terhadap asumsi klasik. Dalam asumsi klasik terdapat beberapa pengujian yang harus dilakukan yakni Uji Normalitas, Uji Multikolonieritas dan Uji Heteroskedastisitas. 


\section{Uji Normalitas}

Uji normalitas bertujuan untuk menguji apakah dalam model regresi, variabel pengganggu atau residual memiliki distribusi normal. Model regresi yang baik adalah memiliki distribusi data normal atau mendekati normal (Ghozali, 2011 : 160). Dasar pengambilan keputusan:

1. Jika data menyebar di sekitar garis diagonal dan mengikuti arah garis diagonal atau grafik histogramnya menunjukan pola distribusi normal maka model regresi memenuhi asumsi normalitas.

2. Jika data menyebar jauh dari garis diagonal dan atau tidak mengikuti arah garis diagonal atau grafik histogram tidak menunjukan pola distribusi normal, maka model regresi tidak memenuhi asumsi normalitas (Ghozali,2011:163).

\section{Uji Multikolinieritas}

Uji multikolinieritas yaitu Jika ditemukan adanya multikolinieritas, maka koefesien regresi variabel tidak tentu dan kesalahan menjadi tidak terhingga (Ghozali, 2011:105). Salah satu metode untuk mendiagnosa adanya multicollinierity adalah dengan menganalisis nilai tolerane dan lawannya variance inflation factor (VIF). Tolerance mengukur variabelitas variabel independent yang terpilih yang tidak dijelaskan oleh variabel independent lalinnya. Nilai tolerance yang rendah sama denga nilai VIF tinggi, karena VIF $=1 /$ Tolerance. Nilai cutoff yang dipakai untuk menunjukkan adanya multikolonieritas adalah nilai 
tolerance kurang dari 0,1 atau sama dengan nilai VIF lebih dari 10 (Ghozali,2011:105).

\section{Uji Heteroskedastisitas}

Tujuan dari pengujian ini adalah untuk menguji apakah dalam model regresi terjadi ketidaksamaan variance dan residul satu pengamatan ke pengamatan lainnya. Model regresi yang baik adalah yang homoskesdastisias, yakni variance dari residual satu pengamatan ke pengamatan lainnya bersifat tetap (Ghozali,2011:139).

\subsection{Uji Hipotesis}

\section{1) Uji Parsial $(U j i-t)$}

Uji t pada dasarnya menunjukan seberapa jauh pengaruh satu variabel bebas secara individual dalam menerangkan variabel terikat.

Rumus uji t (Ghozali, 2006)

$$
t=\frac{r \sqrt{n}-2}{\sqrt{1}-r^{2}}
$$

Keterangan :

$\mathrm{t}=$ nilai $\mathrm{t}$-hitung

$\mathrm{r}=$ nilai koefisien korelasi

$\mathrm{n}=$ jumlah data pengamat

kriteria pengujian :

1. Jika t hitung $>\mathrm{t}$ tabel atau $\mathrm{t} \operatorname{sig}<0,05$ maka $\mathrm{H}_{0}$ diterima.

2. Jika t hitung $<\mathrm{t}$ tabel, atau $\mathrm{t}$ sig $>0,05$ maka $\mathrm{H}_{0}$ ditolak.

\section{2) Uji Simultan (Uji F)}

"Uji F ini digunakan untuk mengetahui pengaruh bersama-sama (simultan) variabel bebas terhadap variabel terikat' (Navrathin Datu 
Sabar, dkk, 2017). Menurut Ghozali (2012:98) “Uji statistik F pada dasarnya menunjukkan apakah semua variabel independen atau variabel bebas yang dimasukkan dalam model mempunyai pengaruh secara bersama-sama terhadap variabel dependen atau variabel terikat', Dasar pengambilan keputusan digunakan dalam uji $\mathrm{f}$ adalah sebagai berikut:

1. Jika $\mathrm{f}$ hitung $>\mathrm{f}$ tabel atau $\mathrm{f}$ sig $<0,05$ maka $\mathrm{H}_{0}$ diterima.

2. Jika f hitung $<\mathrm{f}$ tabel atau $\mathrm{f}$ sig $>0,05$ maka $\mathrm{H}_{0}$ ditolak.

Rumus uji F

$$
F=\frac{R^{2} / K}{(1-R)(n-K-1)}
$$

Keterangan :

$\mathrm{R}=$ koefisien korelasi berganda

$\mathrm{K}=$ jumlah variabel bebas

$\mathrm{N}=$ jumlah sample yang digunakan

\section{DAFTAR PUSTAKA}

Abdi Setiawan, (2018), 'Pengaruh Promosi Jabatan Dan Lingkungan Kerja Terhadap Semangat Kerja Pegawai Di Lingkungan Universitas Pembangunan Pancabudi Medan'”. Jurnal Dosen Fakultas Sosial Sains Universitas Pembangunan Panca Budi. Vol. 8 No. 2. Januari 2018

Abdurrahmat Fathoni. 2006. Manajemen Sumber Daya Manusia. Jakarta : PT. Rineka Cipta.

Alex. S. Nitisemito. 2002. Manajemen Personalia. Edisi Revisi. Penerbit : Ghalia Indonesia.

Asmawi, M. (2017). The effect of compensation, empowerment, and job satisfaction on employee loyalty. International Journal of Scientific Research and Management, 5(12), 7590-7599.

Bambang Wahyudi. (2011). Manajemen Sumber Daya Manusia. Buku 1, Cetakan Ketiga, CV. Bandung : Sulita. 
Bastian Prabowo, Mochammad Al Musadieq dan Ika Ruhana (2016), “Pengaruh

Promosi Jabatan Terhadap Motivasi Kerja Dan Prestasi Kerja (Studi Pada Karyawan Pt Telkom Indonesia Witel Jatim Selatan Malang)'. Jurnal Administrasi Bisnis Fakultas Ilmu Administrasi Universitas Brawijaya Malang (JAB) Vol. 32 No. 1 Maret 2016

Cederyana, Luddin, M. R., \& Supriyati, Y. (2018). “Influence Of Work Discipline, Career Development And Job Satisfaction On Employee Performance Directorate General Research And Development of Ministry Research, Technology And Higher Education'”. International Journal Of Scientific Research And Management (Ijsrm), 6(02), 87-96. Https://Doi.Org/10.18535/Ijsrm/V6i2.E102.

Eko Murtisaputra, Sri Langgeng Ratnasari (2018). 'Pengaruh Lingkungan Kerja, Insentif, Komunikasi Dan Senioritas Terhadap Semangat Kerja Karyawan'. Jurnal Program Studi Magister Manajemen Program Pascasarjana Universitas Riau Kepulauan Dimensi, Vol. 7, No. 3 : 434453 November 2018 Issn: 2085-9996

Esty Pudy Astuti, Sipur, (2019). 'Pengaruh Budaya Organisasi dan Pengembangan Karir terhadap Semangat Kerja Karyawan Pada PT Sentosaraya Abadi Mas"'. Jurnal Ekonomi Universitas Almuslim Bireuen, Vol. XI No. 1 Maret 2019

Handoko, Hani T, 2000. “Manajemen Personalia dan Sumber Daya Manusia. Edisi Ke-2, BPFE',, Yogyakarta.

Hasibuan Melayu SP. 2011. Manajemen Sumberdaya Manusia. Jakarta: PT Bumi Aksara.

Hasibuan, H.M.S.P. 2012. Manjemen Sumber Daya Manusia, Edisi Revisi, Cetakan Kedelapan, Jakarta: Penerbit Bumi Aksara.

Hasibuan, Melayu S.P, 2008, “Manajemen Dasar, Pengertian, dan Masalah, Edisi Revisi”, Bumi Aksara: Jakarta.

Jauhari. 2015. 'Pengaruh Budaya Organisasi Terhadap Semangat Kerja Pegawai Bagian Umum Sekretariat Daerah Kabupaten Boyolali". Jurnal Manajemen Sumber Daya Manusia Universitas Surakarta. Vol. 9 No. 2 Desember 2015

Jumawan, Martin Tanjung Mora, (2018). 'Pengaruh Pelatihan dan Pengembangan Karier Terhadap Kinerja Karyawan Perusahaan Korporasi"'. Jurnal Riset Manajemen dan Bisni (JRMB). Fakultas Ekonomi UNIAT Vol. 3 No. 3 Oktober 2018: 343-352 
Juita, R. (2020). Manajemen Sdm Global (No. 7n9ds). Center for Open Science.

Kaseger, R.G. (2013). 'Pengembangan Karier Dan Self-Efficacy Terhadap Kinerja Karyawan Pada Pt. Matahari Department Store Manado Town Square'. Emba, 1(4), 906-916. Https://Doi.Org/10.1017/Cbo97811074153 24.004.

Kudsi, M. R., Riadi, S. S., \& As, D. L. (2017). “Pengaruh Pengembangan Karier Dan Sistem Insentif Terhadap Kinerja Karyawan’’. Jurnal Manajemen, 9(2), 85-93.

Mangkunegara, A P. (2017). Manajemen Sumber Daya Manusia Perusahaan. Bandung: PT. Remaja Rosdakarya.

Mangkunegara, Anwar Prabu. 2011. Manajemen Sumber Daya Manusia, Bandung : Rosda.

Manullang. 2018. Dasar-Dasar Manajemen. Yogyakarta: Ghalia Indonesia (GI).

Margono. 2007. Metodologi Penelitian Pendidikan. Jakarta: Rineka Cipta.

Moekijat. 2010. Manajemen Sumber Daya Manusia. Cetakan Kesembilan. Bandung : Penerbit CV Mandar Maju Cetakan Kesembilan. Bandung : Penerbit CV Mandar Maju.

Munandar. 2014. Manajemen Sumber Daya Manusia. Jakarta: Graha Ilmu.

Napitupulu, S., Haryono, T., \& Laksmi Riani, Et. Al. (2017). "The Impact Of Career Development On Employee Performance: An Empirical Study Of The Public Sector In Indonesia'. Internationa Review Of Public Administration,22(3),276-299.

Ni Komang Tri, A.A Sagung Kartika Dewi (2017). “Pengaruh Loyalitas, Prestasi Kerja Dan Kompetensi Terhadap Promosi Jabatan Di Pt. Pln (Persero) Distribusi Bali"'. Fakultas Ekonomi dan Bisnis Universitas Udayana, Bali, Indonesia 2017

Nitisemito dan Darmawan. 2013. Metode Penelitian Kuantitatif. Bandung: Remaja Rosdakarya.

Nitisemito, A. (2008). Manajemen Personalia. (Edisi Kedua). Jakarta : Ghalia Indonesia.

Nitisemito, A. (2010). Manajemen Personalia. (Edisi Kede). Jakarta : Ghalia Indonesia. 
Nurmansyah. 2011. Manajemen Sumber Daya Manusia Suatu Pengantar. Hal.260. Pekanbaru: Unilak Press.

Onsardi, O. (2018). Loyalitas Karyawan pada Universitas Swasta di Kota Bengkulu. COSTING: Journal of Economic, Bussines and Accounting, 2(1), 1-13.

Onsardi, O. (2020). Manajemen Sumber Daya Manusia (No. yq85t). Center for Open Science.

Rachmawati, I.K. 2008. Manajemen Sumber Daya Manusia, Yogyakarta: Penerbit Andi.

Regina, G. K. (2013). Pengembangan Karir dan Self-Efficacy Terhadap Kinerja Karyawan Pada PT. Matahari Departement Store Manado Town Square. Jurnal EMBA, 1 (4), 906-916.

Rivai, V dan Sagala, E. J., 2009. “Manajemen Sumber Daya Manusia Untuk Perussahaan : Dari Teori ke Praktek PT. Rajagrafindo Persada”. Jakarta.

Siagian, P. Sondang. (2010). Manajemen Sumber Daya Manusia, Jakarta: Bumi Aksara, Cetakan Kesembilan

Siagian, S. P. (2015). Manajemen Sumber Daya Manusia. Jakarta : Bumi Aksara.

Sinambela, L. P. (2016). Manajemen Sumber Daya Manusia: Membangun Tim Kerja yang Solid untuk Meningkatkan Kinerja. Jakarta : Bumi Aksara.

Sinollah, (2012). “Analisis Pelaksanaan Program Promosi Jabatan Dampaknya Terhadap Semangat Kerja Karyawan Pada Uptd Pendidikan Tk Dan Sd Kec. Klemahan"’. Jurnal OTONOMI Vol. 12 No.4. Oktober 2012

Siswanto Sastrohadiwiryo. (2005). Manajemen Tenaga Kerja Indonesia. Jakarta:Bumi Aksara, Cetakan Kelima

Sri widodo. 2015. Sistem Informasi manajemen. Bandung: Manggu Media.

Sugiyono. (2016). Metode Penelitian Kuantitatif Dan Kualitatif Dan R\&D. Bandung: Alfabeta.

Sugiyono. 2012. Metode Penelitian Kuntitatif, Kualitatif, dan R\&D. Bandung: Alfabeta.

Sugiyono. 2014. Metode Penelitian Pendidikan Pendekatan Kuntitatif, Kualitatif, dan $R \& D$. Bandung: Alfabeta. 
Thoriq Rijalulloh, dkk. (2017). “Pengaruh Pengembangan Karir dan Promosi Jabatan Terhadap Semangat Kerja (Studi Pada Karyawan Perusahaan Daerah Air Minum Kota Malang)'”. Jurnal Administrasi Bisnis Fakultas Ilmu Administrasi (JAB), Vol. 51 No. 2 Oktober 2017

Widodo, S.E. (2015). Manajemen Pengembangan Sumber Daya Manusia(Edisi Kedu). Yogyakarta: Pustaka Pelajar.

Winda Annisa Putri dan Agus Frianto (2019). “Pengaruh Pengembangan Karier Terhadap Motivasi Dan Dampaknya Terhadap Kinerja Karyawan (Studi Kasus Di Pt. Barata Indonesia (Persero) Gresik)', Jurnal Ilmu Manajemen, Fakultas Ekonomi Universitas Negeri Surabaya Vol. 7 No. 2 2019 